INTER NATIONAL MONETARY FUND
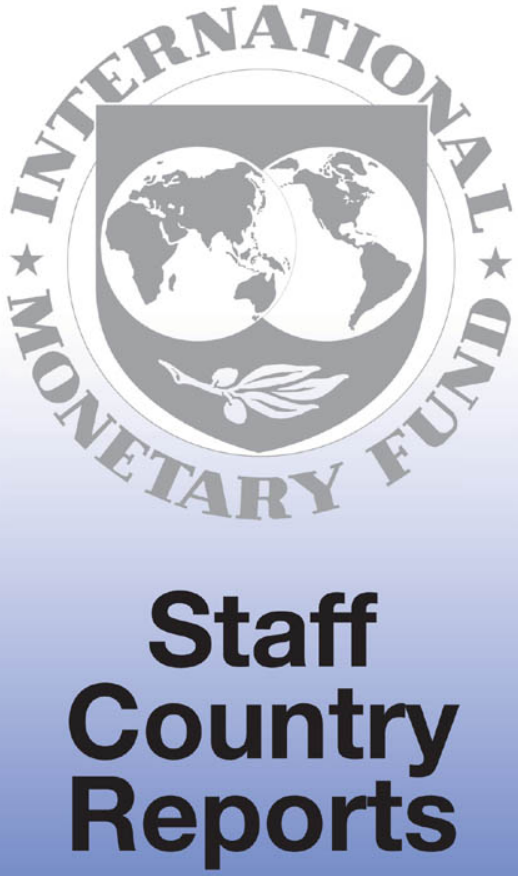


\section{Cyprus: Selected Issues Paper}

This paper was prepared based on the information available at the time it was completed on November 4, 2011. The views expressed in this document are those of the staff team and do not necessarily reflect the views of the government of Cyprus or the Executive Board of the IMF.

The policy of publication of staff reports and other documents by the IMF allows for the deletion of market-sensitive information.

Copies of this report are available to the public from

International Monetary Fund • Publication Services 700 19th Street, N.W. • Washington, D.C. 20431

Telephone: (202) 623-7430 • Telefax: (202) 623-7201

E-mail: publications@imf.org • Internet: http://www.imf.org

\section{International Monetary Fund Washington, D.C.}


This page intentionally left blank

CInternational Monetary Fund. Not for Redistribution 


\section{INTERNATIONAL MONETARY FUND}

\section{CYPRUS}

\section{Selected Issues}

Prepared by Mustafa Saiyid (MCM), Alejandro Simone (EUR), Anke Weber (FAD), Mai Chi Dao (EUR)

Approved by the European Department

November 4, 2011

Contents

I. Cyprus Banking Sector Vulnerabilities

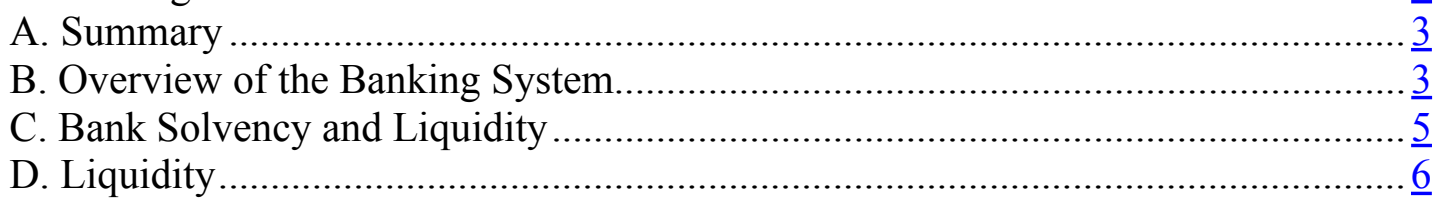

II. The Cypriot Pension System: Issues and Reform Options …………………................ $\underline{8}$

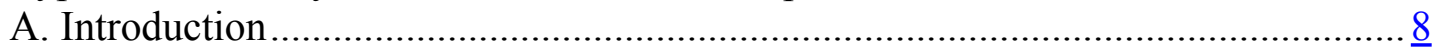

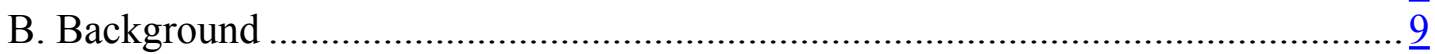

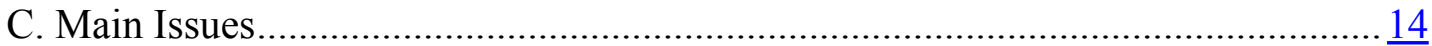

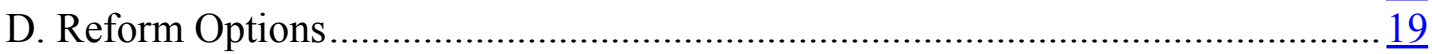

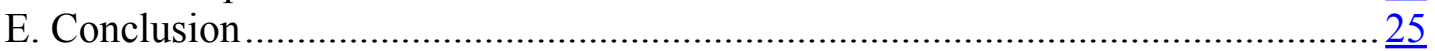

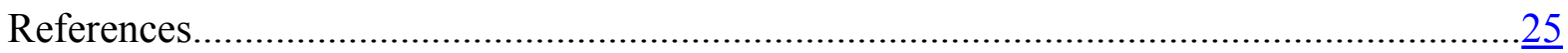

III. Strengthening Public Financial Management and Managing Fiscal Risks...................... $\underline{32}$

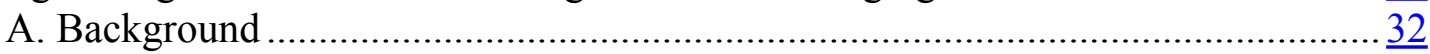

B. Status of Reforms and Main Outstanding Issues ............................................... $\frac{33}{37}$

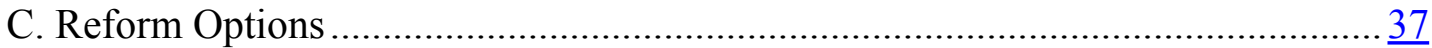

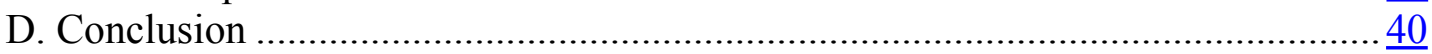

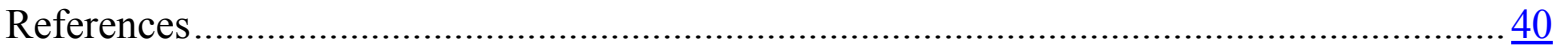

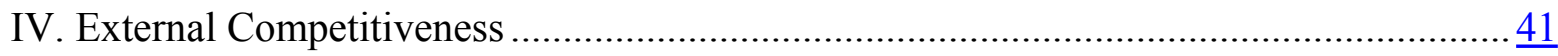

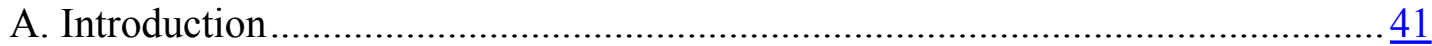

B. Labor Market Indicators.............................................................................

C. The Evolution of Service Exports .......................................................... $\frac{45}{47}$

D. The Role of Relative Prices ....................................................................... 47

E. Other Aspects of competitiveness ………………........................................ $\frac{50}{51}$

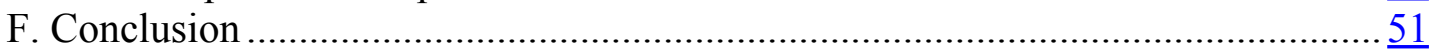


Annex

References.

Tables

I. Cyprus Banking Sector Vulnerabilities

1. Accounts of the Social Insurance Fund ......................................................... 10

2. Current and Future contribution on Rates Based on Legislation........................... 11

3. GSIS and Public Sector Employee Schemes Compared...................................... 12

4. Net Cost of Pension Schemes for Public Employees........................................... 13

5. Projected Accounts of the Social Insurance Fund ……….................................. 14

6. Long-term Projections of the Social Insurance Fund............................................... 15

III. Strengthening Public Financial Management and Managing Fiscal Risks

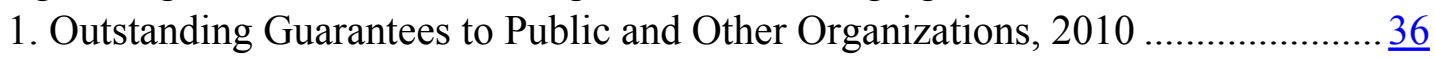

2. PPP Projects and Their Estimated Costs............................................................ $\frac{36}{36}$

IV. External Competitiveness

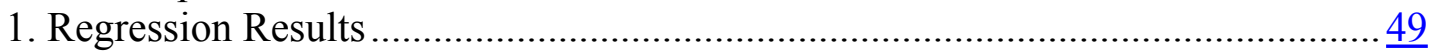

2. Regression Results with Interaction Terms .................................................... 49

Figures

IV. External Competitiveness

1. Cyprus Labor Market in Regional Perspective.................................................... 44

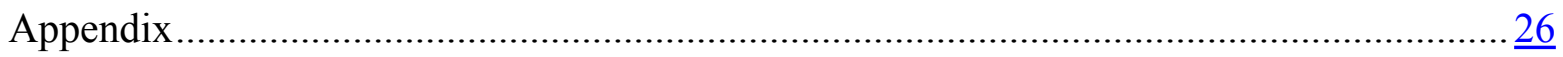

Boxes

A1. Old Age Pension GSIS Formula.......................................................................

A2. Underlying Data Assumptions for Projections................................................ 27

Tables

A1. Actuarial Penalties for Early Retirement........................................................

A2. Life Expectancy at Age 65.........................................................................

A3. Pension Indexation Practices in National Pension Schemes................................

A4. Public Pension Contribution Rates and Gross Replacement

Rates in the OECD 34............................................................................

A5. Age of Mandatory Retirement in Civil Service Pension Schemes........................

A6. Pension Accrual Rates in Civil Service Schemes.................................................

A7. Method of Pension Indexation in Civil Servants Pension Schemes.......................31 


\section{Cyprus Banking Sector Vulnerabilities ${ }^{1}$}

\section{A. Summary}

- The most salient risks come from commercial banks domiciled in Cyprus. These banks have the strongest links with the local economy, are most heavily exposed to significant haircuts on Greek government bonds, and are likely to experience further deterioration of their loan portfolios in both Greece and Cyprus. Risks from other financial institutions operating in Cyprus should not be overlooked, but they are not the main focus of this report.

- $\quad$ Cyprus banks face capital needs estimated at $€ 3.6$ billion on a preliminary basis by the EBA. Cyprus banks would need this much of a buffer against losses on sovereign debt holdings in order to reach a core Tier 1 capital ratio of 9 percent. In the event of additional shocks such as acceleration in the pace of NPL formation, capital needs could increase.

- It is unclear how banks will raise necessary capital. They are expected to de-lever balance sheets, issue contingent convertible securities, retain profits and cut costs. If these sources prove inadequate, they would need the support from the government or external sources.

The system appears capable of absorbing moderate funding shocks at the aggregate level, but individual banks could face pressures. In the event of rapid and persistent loss of deposits, liquidity buffers would eventually be depleted.

\section{B. Overview of the Banking System}

1. The size of the banking system in relation to the economy magnifies the potential impact of any balance sheet risks. Assets of the entire system total nearly 8.5 times GDP. The Cypriot banking system is comprised of four different types of institutions: domestic commercial banks; cooperative credit institutions; subsidiaries of foreign banks; and branches of foreign banks.

\begin{tabular}{|c|c|c|c|c|c|c|c|c|c|c|}
\hline \multicolumn{11}{|c|}{$\begin{array}{l}\text { Cyprus: Structure Of The Banking System } \\
\text { (Billions of euros) }\end{array}$} \\
\hline & $\begin{array}{l}\text { Loans (net of } \\
\text { provisions) }\end{array}$ & $\begin{array}{l}\text { Cyprus } \\
\text { loans to } \\
\text { residents }\end{array}$ & $\begin{array}{c}\text { Cyprus } \\
\text { loans to } \\
\text { non- } \\
\text { residents }\end{array}$ & $\begin{array}{l}\text { Loans in } \\
\text { Greece }\end{array}$ & $\begin{array}{c}\text { Securities } \\
\text { and other } \\
\text { investments }\end{array}$ & $\begin{array}{l}\text { Of which: } \\
\text { sovereign } \\
\text { bonds }\end{array}$ & $\begin{array}{l}\text { Of which: } \\
\text { Greek } \\
\text { government } \\
\text { bonds }\end{array}$ & $\begin{array}{l}\text { Interbank } \\
\text { assets }\end{array}$ & $\begin{array}{l}\text { Total } \\
\text { assets }\end{array}$ & $\begin{array}{l}\text { Percentage } \\
\text { of GDP }\end{array}$ \\
\hline System & 91.4 & 43.2 & 17.8 & 23.4 & 28.7 & 14.7 & 7.2 & 24.8 & 152.0 & 835 \\
\hline Branches of foreign banks & 2.1 & 0.4 & 1.8 & 0.0 & 0.5 & 0.2 & 0.0 & 4.8 & 7.6 & 42 \\
\hline Subsidiaries of foreign banks & 16.5 & 6.1 & 10.4 & 0.0 & 11.5 & 4.0 & 2.4 & 6.4 & 35.3 & 194 \\
\hline Cooperative banks & 12.4 & 12.4 & 0.0 & 0.0 & 2.3 & 2.1 & 0.1 & 1.1 & 16.9 & 93 \\
\hline \multirow[t]{2}{*}{ Commercial banks } & 60.3 & 24.3 & 5.6 & 23.4 & 14.3 & 8.4 & 4.7 & 12.4 & 92.1 & 506 \\
\hline & Total deposits & $\begin{array}{l}\text { Cyprus } \\
\text { deposits } \\
\text { from } \\
\text { residents }\end{array}$ & $\begin{array}{l}\text { Cyprus } \\
\text { deposits } \\
\text { from non- } \\
\text { residents }\end{array}$ & $\begin{array}{l}\text { Deposits } \\
\text { raised in } \\
\text { Greece }\end{array}$ & & $\begin{array}{c}\text { Liabilities } \\
\text { to parent } \\
\text { banks }\end{array}$ & $\begin{array}{c}\text { Interbank } \\
\text { Liabilities (ex } \\
\text { parent) }\end{array}$ & $\begin{array}{l}\text { Capital } \\
\text { and } \\
\text { reserves }\end{array}$ & $\begin{array}{c}\text { Total } \\
\text { liabilities }\end{array}$ & $\begin{array}{l}\text { Percentage } \\
\text { of GDP }\end{array}$ \\
\hline System & 93.8 & 37.3 & 33.8 & 17.3 & & 21.1 & 18.6 & 14.2 & 152.0 & 835 \\
\hline Branches of foreign banks & 5.5 & 0.8 & 4.6 & 0.0 & & 0.9 & 1.0 & 0.2 & 7.6 & 42 \\
\hline Subsidiaries of foreign banks & 10.0 & 4.2 & 5.8 & 0.0 & & 20.2 & 2.7 & 1.9 & 35.3 & 194 \\
\hline Coops & 13.8 & 13.6 & 0.2 & 0.0 & & 0.0 & 1.1 & 1.5 & 16.9 & 93 \\
\hline Commercial Banks & 64.5 & 18.6 & 23.1 & 17.3 & & 0.0 & 13.8 & 10.6 & 92.1 & 506 \\
\hline
\end{tabular}

\footnotetext{
${ }^{1}$ Prepared by Mustafa Saiyid (October 2011).
} 
2. A focus on domestic commercial banks is warranted by their large size, significant interaction with the local economy and high exposure to Greece. Domestic commercial banks have assets of $€ 92$ billion, or 5 times GDP. Three banks account for nearly 98 percent of their assets, and the two largest (Marfin and Bank of Cyprus) comprise nearly 88 percent. The asset portfolio of commercial banks consists largely of loans (66 percent); followed by holdings of securities (16 percent); interbank assets (13 percent); and fixed assets. Direct lending in Cyprus is $€ 30$ billion (166 percent of GDP), of which the bulk, $€ 24$ billion, is to Cyprus residents. Greek asset exposure amounts to $€ 23.4$ billion in direct loans and $€ 4.7$ billion of Greek government, along with $€ 0.6$ billion in Greek bank bonds. At more than 25 percent of GDP, Cyprus banks have the

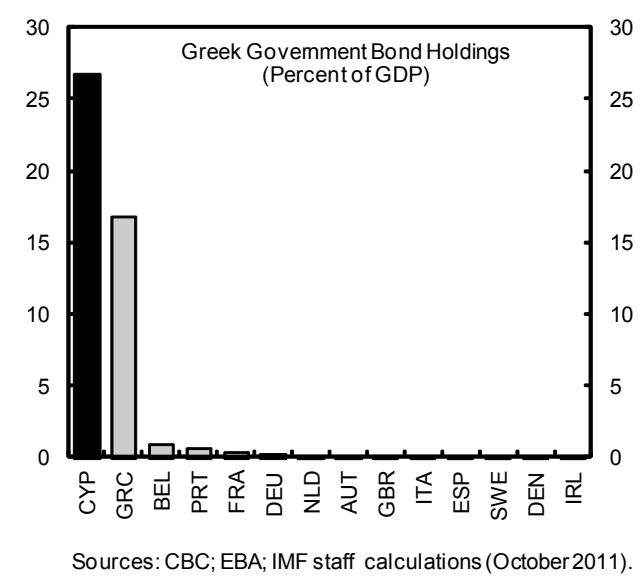
highest exposure to Greek government bonds of any country's banking system. Holdings of Cypriot government bonds are $€ 1.6$ billion. The CT1 capital ratio of the system is 8.6 percent as of June 2011. Loans in 90-day arrears on local operations of domestic banks are 13.9 percent of the book and have been rising sharply since end-2009.

3. Cooperative credit institutions are heavily exposed to the local economy with little exposure to Greece. Cooperative credit institutions ("cooperatives") have assets of $€ 16.9$ billion. These have $€ 12.4$ billion worth of loans to Cypriot residents. On the liability side, they have deposits of $€ 13.8$ billion, overwhelmingly from Cypriot residents. Greek exposure amounts to $€ 144$ million of government bonds. Holdings of Cypriot government bonds are $€ 1.9$ billion. The CT1 ratio, which is the same as the Tier 1 ratio for cooperatives, is 10.2 percent. Loans in 90-day arrears are 27 percent of the book.

\section{Subsidiaries of foreign banks are much less connected with the local economy} and have mainly indirect Greek exposure. Foreign bank subsidiaries, mostly Greek, have assets of $€ 35.3$ billion (almost twice GDP). They provide $€ 16.5$ billion of direct loans in Cyprus, of which $€ 6.1$ billion are to Cypriot residents. Against this, they have $€ 10$ billion worth of deposits raised in Cyprus, of which $€ 4.2$ billion are from Cypriot residents. These subsidiaries rely mainly on parent banks for funding. Direct exposure to Greece is only through $€ 2.4$ billion worth of holdings of Greek government bonds, which are held by a single institution. CT1 capital ratios are generally above 12 percent. Loan portfolio arrears are below other categories of institutions, 10 percent or lower.

\section{Branches of foreign banks have little interaction with the local economy.} Branches of foreign banks have $€ 7.6$ billion in assets and the bulk of these come from banks domiciled outside the EU, principally from the Middle East. Out of $€ 2.1$ billion in loans, $€ 1.8$ billion is directed to non-residents; while on the liability side, out of $€ 5.5$ billion 
in deposits, $€ 4.6$ billion is raised from non-residents. The non-resident business, involving short-term deposits, is mainly with offshore companies and is motivated by tax considerations. $^{2}$

\section{Bank Solvency and Liquidity}

\section{Solvency}

6. The EBA estimates on a preliminary basis bank capital needs of $€ 3.6$ billion (20 percent of GDP) to reach a core Tier 1 capital ratio of 9 percent and create a buffer against losses on sovereign debt. As of end-June 2011, the CT1 ratio of the system was 8.6 percent. With capital at the level mandated by the EBA, banks could absorb deterioration in 90-day arrears of loan portfolios from the present level of 13.9 percent to 21 percent before the system CT1 ratio would fall to 6 percent.

\section{The current core Tier 1 ratio does not directly show the boost to capital from} issuance of contingent convertible securities. Out of nearly $€ 1.5$ billion in gross capital issuance during 2011 year-to-date, $€ 955$ million has come from the issuance of contingent convertible bonds (CoCos). These securities do not count in the CT1 ratio unless it falls below the regulatory minimum, in which case they convert to common equity. However, the principal buyers of this issuance have been existing debt and equity holders of banks. $€ 696$ million of gross issuance of CoCos has been used for conversion of other hybrid debt, and the remaining €259 million placed with existing equity holders. Bank equity valuations have fallen by more than half during

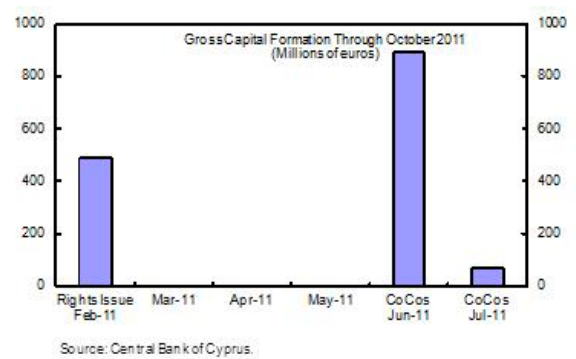
2011. As of mid-October, shares of two of the three large banks were trading at valuations of 30 to 40 cents, while the third was at roughly one euro. At these valuations banks are likely to have difficulty raising equity capital.

\section{The most important balance sheet risk for commercial banks is from holdings of}

Greek securities. Losses on bank holdings of Greek government and bank bonds would be an estimated $€ 2.7$ billion using the October 26, 2011 PSI agreement haircut of 50 percent. In addition, mark-to-market losses on Cypriot government securities are an estimated $€ 0.3$ billion. However, Cypriot banks have already recognized market losses on $€ 0.5$ billion on Greek government debt, corresponding to an average impairment of 11.5 percent, according to second quarter filings.

\footnotetext{
${ }^{2}$ A sample transaction arranged by these banks would be for the payment of goods and services between two companies registered in Cyprus but with no physical location there. Deposit rates for balances of these companies are generally much lower than those offered on other types of accounts.
} 


\section{Further deterioration in loan}

\section{portfolios is likely. Deteriorating}

macroeconomic conditions have led to a pickup in 90-day arrears on loan portfolios over the 2010-2011 period from 9.8 percent at end-December 2009 to 13.9 percent by endJune 2011. ${ }^{3}$ As the domestic macroeconomic situation continues to weaken, some Cypriot banks project that arrears could go to 20 percent on the domestic portfolio and 22 percent on their Greek loan portfolios. Meanwhile, provisions in relation to arrears are falling.

\section{Liquidity}

\section{The funding profile of domestic commercial banks is dominated by deposits.}

Deposits raised locally are $€ 41.8$ billion of which $€ 18.6$ billion, or less than half, come from residents; the remaining $€ 23.1$ billion from non-residents. Non-resident deposits come largely from Russia and to a lesser extent from other CIS states. ${ }^{4}$ Deposits raised in Greece amount to $€ 17$ billion or about one-third of all deposits. Cypriot banks have loan-to-deposit ratios of 93 percent. Interbank funding, not including that from central banks, is only 6.5 percent of liabilities, while debt market funding is only 2.3 percent, as of end-June 2011. Since June, the two largest banks have raised $€ 1.2$ billion in funding through the issuance of covered bonds, a development supported by the passage of a covered bond law in December 2010. Capital market debt refinancing needs are close to $€ 0.5$ billion through 2012 .

\section{Banks have been losing deposits since} mid-year. Deposits rose between January and May, but have since fallen by nearly nearly 4.5 percent. At end-September, deposits were 0.7 percent below end-2010 levels. Deposit outflows

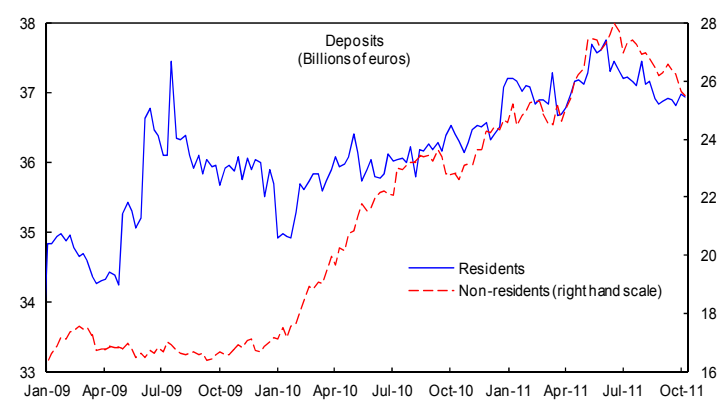

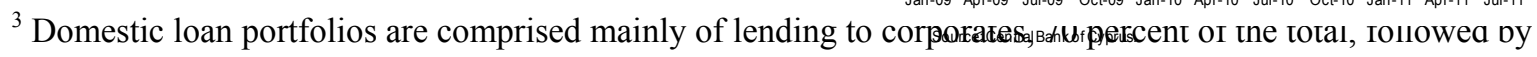
mortgages, 20 percent, and consumer loans, 10 percent. Almost half of corporate lending is to small and medium size enterprises (SMEs).

${ }^{4}$ Based on estimates of banking supervisors and banks; no official data on country of origin is available. 
have been mainly from Greek branches of Cypriot banks. Historically, non-resident deposits, particularly those of brass plate companies, have been much more volatile than overall system deposits. $€ 27$ billion in deposits are guaranteed by the deposit insurance fund.

\section{Correspondingly, the overall} liquidity situation of the banking system has deteriorated and banks' use of ECB funding has risen.

Liquid assets, as a percentage of liabilities maturing in one year or less, dropped from a peak of 64 percent in Q2 2009 to 44 percent in Q1 2011, a figure that put Cypriot bank liquidity below the median in comparison with other European banking systems.

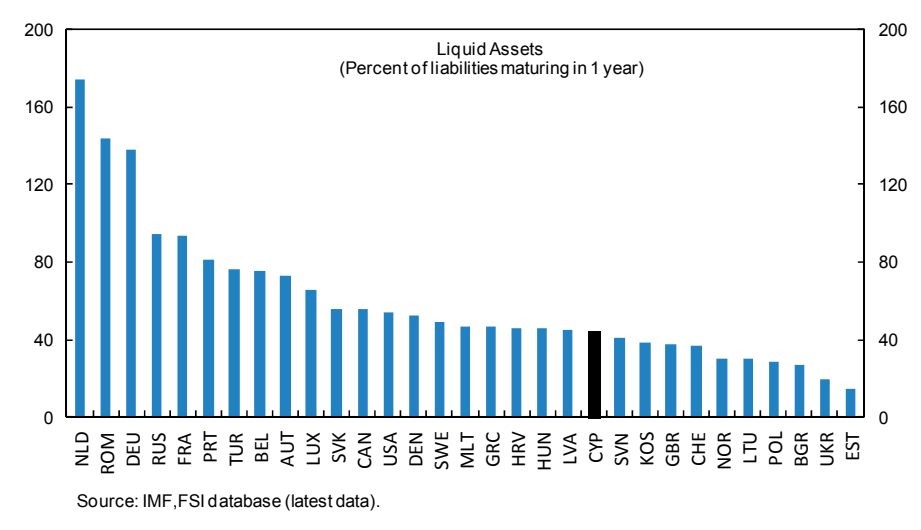

13. A simple liquidity stress test suggests that the domestic banking system as a whole would be able to withstand a moderate funding shock. The test suggests that domestic commercial banks would be able to withstand a 20 percent loss of non-resident deposits, a 10 percent loss of resident deposits, and a 50 percent contraction in interbank funding within a one-week period. The prudential liquid asset requirement of 70 percent against foreign currency deposits and 20 percent against local currency deposits set by the CBC provides an important buffer (about half of non-resident deposits are denominated in a foreign currency). Funding in this scenario would come from interbank assets and the ECB. However, the topdown nature of the analysis masks individual bank vulnerabilities. Also, further analysis would be needed to determine if assets classified as liquid would, in fact, prove to be so in a crisis situation.

\section{Further sovereign downgrades could reduce collateral available for ECB funding.}

The present rating of Baa / BBB is only two notches away from a below-investment grade rating. Further downgrades are possible since the sovereign carries a negative outlook from the three principal rating agencies. Under current rules, if the sovereign rating falls below investment grade, government securities could no longer be eligible as collateral for ECB refinancing facilities. Cyprus banks hold close to $€ 4$ billion in Cypriot sovereign debt collateral, including $€ 2.2$ billion of special government bonds from the 2009 scheme that provided banks with government bonds against loan collateral to access ECB funding. 


\section{The CyPRIOT PENSION SySTEM: ISSUES AND REForm OPTIONS ${ }^{1}$}

Public Pension expenditures will roughly double by 2050 far outstripping planned increases in contributions. If unreformed, spending on public pension schemes is expected to rise from about 9 percent of GDP in 2010 to about 19 percent of GDP by 2050 and drive public pension expenditures to be among the largest in the EU. The increase in outlays is expected to exceed by a wide margin the planned increases in contributions from employees and employers of about 3 percent of GDP and would thus require an increase in government transfers of 7 percent of GDP. By 2020 the need for government transfers is projected to increase by about 1.5 percent of GDP. Spending on non contributory pension schemes would add further to the fiscal burden. These developments will put an unsustainable burden on public finances. Reforms to ensure fiscal sustainability should start now.

\section{A. Introduction}

1. Publicly provided schemes dominate the Cypriot pension system. The main pension schemes are the General Social Insurance Scheme (GSIS) run by the Social Security Fund (SSF) and the Government Employees Pension Scheme (GEPS) run by the Ministry of Finance. The first covers public and private sector workers while the latter provides an occupational pension for central government employees. GSIS pension spending was about 6 percent of GDP while GEPS pension spending was close to 2.5 percent of GDP, accounting for roughly 85 percent of 2010 total pension spending. Other public schemes include broader public sector pensions (BPSS), which cover local governments and a variety of public entities outside the central government including public corporations (about 0.5 percent of GDP), and non-contributory pension schemes (1 percent of GDP $)^{2}$. Privately provided schemes include provident funds and occupational pension schemes which accounted for slightly less than 5 percent of total pension spending in 2008.

\section{This paper analyzes the main factors behind the expected increase in the} budget cost of public pension spending and discusses reform options. In its analysis, the paper compares the parameters of the Cypriot pension schemes with those of other OECD countries. The paper focuses on the GSIS, GEPS, and BPSS given that they account for the bulk of pension expenditures. Section B provides background on these

\footnotetext{
${ }^{1}$ Prepared by Alejandro Simone(EUR).

2 The non contributory pension schemes are the special allowance to pensioners (SATP) and the social pension. (SP). In 2010, the SATP paid an allowance for pensioners whose total pension income from any other schemes did not exceed a minimum per year guaranteeing a minimum pension benefit. The SP provides pensions to Cypriot residents of 65 years or more who have no pension income from any other source.
} 
schemes main parameters, Section C discusses main issues, and Sections D and E conclude with a discussion of reform options.

\section{B. Background}

\section{General Social Insurance Scheme}

3. The GSIS provides short-term benefits and long-term benefits to its insured population. Short-term benefits include the sickness benefit, the maternity benefit, a marriage grant, unemployment benefits, and an employment injury benefit. Long term benefits include pensions for old age, invalidity and survivors. The scheme was created in 1957 and since 1964 extends compulsory insurance to every person employed in Cyprus, both in public and private sector, including all categories of self-employed. In 1980, a supplementary earnings-related insurance scheme replacing the previous scheme of flat-rate contributions and benefits was introduced.

4. Contribution rates differ between the employed and self-employed persons. Contribution rates for employed persons are $13.6 \%$ of their gross insurable earnings, shared equally between the employer and the employee, and 12.6 for the self-employed. The contribution rate for employed persons includes about 1 percent of gross earnings for unemployment insurance. The central government pays an additional contribution of $4.3 \%$ of gross insurable earnings on top of its normal contribution as an employer.

\section{The level of the pension benefit depends on the length of the contribution} period and the level of gross insurable earnings. Pension benefits have two components: a basic pension and a supplementary pension based on the level of gross insurable earnings. The earnings on which contributions and benefits are calculated (gross insurable earnings), are divided into a "lower" and an "upper" band, with the "lower band" consisting of earnings up to a certain "basic" level. The "upper band," consists of earnings in excess of the "basic" level up to a maximum limit of six times the threshold of the lower band. Insured persons are credited each year with "insurance points". One insurance point is credited for each multiple of the yearly amount of annual basic insurable earnings defined by the government. The basic pension is indexed yearly to the annual increase of the average gross insurable earnings while the supplementary pension is indexed to the consumer price index. Box 1 in the Appendix discusses the pension formulas for the basic and supplementary pension and illustrates the computation of an old age GSIS pension for a hypothetical case.

\section{The pensionable age is 65 years for both men and women but early} retirement is common. Early retirement pensions can be drawn without reduction in 
benefits at the age of 63 under certain conditions ${ }^{3}$. While incentives are provided for postponing retirement, these are not enough to offset the incentives provided by the absence of an early retirement penalty since the average effective retirement age is about 63.6 years ${ }^{4}$. Old-age pensioners can continue work and earn income without prejudice to their pension benefits.

\section{The GSIS has run small deficits in recent years excluding the additional}

government contribution and interest income (Table 1). For the purposes of this paper, which involve analyzing the financing needs that the GSIS places on the government, government transfers to GSIS excluding those related to its role as an employer are excluded from the revenues of the SSF. In particular, given that the reserves of the SSF are almost fully invested in government instruments (see below), the interest income paid by the government is akin to a transfer and thus excluded from the revenues. Given this definition of revenues, the social security fund has been running a small deficit which was stable in 2006-2009 but grew in 2010. Buoyant economic activity until end-2008 and an increase in pension contributions in 2009 supported revenues and contributed to the stable deficit in spite of increasing pension and unemployment benefit outlays. The latter reflect increasing unemployment related to the global crisis in 2009. Estimates for 2010 suggest a more rapid growth of benefit expenditure than contribution revenue.

Table 1. Accounts of the Social Insurance Fund (Percent of GDP)

\begin{tabular}{lrrrr}
\hline & 2007 & 2008 & 2009 & 2010 \\
\hline Total revenue & 4.9 & 5.1 & 5.8 & 5.9 \\
$\quad$ Contribution from employees and employers & 4.8 & 5.0 & 5.6 & 5.8 \\
$\quad$ Other current revenue & 0.1 & 0.1 & 0.2 & 0.2 \\
Total expenditure & 5.1 & 5.3 & 5.9 & 6.3 \\
$\quad$ Current expenditure & 5.1 & 5.3 & 5.9 & 6.3 \\
$\quad$ Goods and services & 0.1 & 0.1 & 0.1 & 0.1 \\
$\quad$ rransfers & 5.1 & 5.2 & 5.8 & 6.3 \\
$\quad$ Unemployment benefits & 0.3 & 0.3 & 0.5 & 0.5 \\
$\quad$ Benefits & 4.7 & 4.9 & 5.4 & 5.8 \\
$\quad$ Old age and early retirement pensions & 4.3 & 4.5 & 4.9 & 5.3 \\
$\quad$ Other benefits & 0.4 & 0.4 & 0.5 & 0.5 \\
$\quad$ Capital expenditure & 0.0 & 0.0 & 0.0 & 0.0 \\
$\quad$ Gross fixed capital formation & 0.0 & 0.0 & 0.0 & 0.0 \\
Overall balance & -0.2 & -0.2 & -0.2 & -0.4 \\
Memorandum items: & & & & \\
Overall balance including government contributions and interest income & 2.6 & 3.0 & 2.3 & 2.0 \\
Government contributions & 1.5 & 1.6 & 1.8 & 1.8 \\
Interest Income & 1.2 & 1.6 & 0.7 & 0.6 \\
\hline Sources: Final Accounts of the Social Security Fund 2006-2009 and preliminary $2010 ;$ and IMF staff estimates
\end{tabular}

Sources: Final Accounts of the Social Security Fund 2006-2009 and preliminary 2010; and IMF staff estimates

\footnotetext{
${ }^{3}$ The conditions for being eligible for early retirement in the GSIS are: (1) have paid contributions in at least three years and have insurable earnings in the lower band not less than 156 times the weekly basic earnings; and (ii) have a weekly average of insurable earnings (paid or credited) in the lower band of at least $70 \%$ of the weekly amount of the basic insurable earnings (paid or credited).

${ }^{4}$ Incentives for postponing retirement translate into an increase of 0.5 percent in the pension benefit for every postponed month from age 65 up to a maximum of age 68 .
} 
8. The GSIS was designed to be partially funded but is de facto operating on a pay- as-you-go basis. Given that the total contribution rate including the government contribution was set a higher levels than needed to fund benefits at the inception of the scheme, the social security law establishes that annual surpluses should be deposited to a special reserve of the social security fund and the size of that reserve should not be below two years of total annual pension spending. In practice, however, the excess of annual contributions over benefits was invested almost exclusively in government securities. The size of this special reserve at the end of 2010 was about 7 billion euros ( 40 percent of GDP) and government securities represent 93 percent of the total. Thus, rather than a reserve to buffer imbalances between revenues and expenditures, it represents a commitment of the government vis-a-vis the GSIS to meet future shortfalls when they arise as in standard pay-as-you-go systems.

\section{The last reform of the GSIS was in $\mathbf{2 0 0 9}$ and focused on improving long-term}

financial sustainability. The main measure taken was a gradual increase in the contribution rate for employees and employers by 1 percentage point every five years raising it from 12.6 percent at end 2008 to 19.6 percent in January 2039, starting in January 2009 (Table 2). Other measures tightened the eligibility conditions including increasing the minimum qualifying period to be eligible for pension and restricting the crediting of contributions for full time education ${ }^{5}$.

Table 2. Current and Future Contribution Rates Based on Legislation (Percent)

\begin{tabular}{|c|c|c|c|c|c|c|c|}
\hline & 2009-2013 & 2014-2018 & 2019-2023 & $2024-2028$ & 2029-2033 & $2034-2038$ & $2039+$ \\
\hline $\begin{array}{l}\text { Basic and } \\
\text { supplementary }\end{array}$ & 15.6 & 16.9 & 18.2 & 19.5 & 20.8 & 22.1 & 23.4 \\
\hline Other & 2.3 & 2.3 & 2.3 & 2.3 & 2.3 & 2.3 & 2.3 \\
\hline Total & 17.9 & 19.2 & 20.5 & 21.8 & 23.1 & 24.4 & 25.7 \\
\hline Employee & 6.8 & 7.3 & 7.8 & 8.3 & 8.8 & 9.3 & 9.8 \\
\hline Employer & 6.8 & 7.3 & 7.8 & 8.3 & 8.8 & 9.3 & 9.8 \\
\hline Government & 4.3 & 4.6 & 4.9 & 5.2 & 5.5 & 5.9 & 6.2 \\
\hline Total & 17.9 & 19.2 & 20.5 & 21.8 & 23.1 & 24.4 & 25.7 \\
\hline
\end{tabular}

\section{Pension Schemes for Public Employees (GEPS and OPSS)}

\section{The GEPS provides supplementary retirement and survivors pensions to} central government employees. This includes civil servants, members of the educational service, the police, and the armed forces. The GSIS pays the pension of public employees just as for private sector employees (basic+supplementary) but the supplementary portion

\footnotetext{
${ }^{5}$ The minimum qualifying period of paid contributions for old age pension was increased from three to ten years and the total period, including credited contributions, from 12 to 15 years within a period of three years starting from 2009. In addition, the minimum contribution period for entitlement to an old age grant (payable where there is no entitlement to pension) was raised from three to six years. The crediting of contributions for full time education for old age pension was restricted to 6 years.
} 
of the GSIS pension is counted as partial payment of the GEPS supplementary pension ${ }^{6}$. The GEPS supplementary pension has been financed until recent reforms in August 2011 (see below) almost entirely by general taxation since participation of employees in the financing of GEPS pension was limited to an average 0.8 percent contribution rate of their gross earnings to pay for survivors' pensions.

Table 3. GSIS and Public Sector Employee Schemes Compared

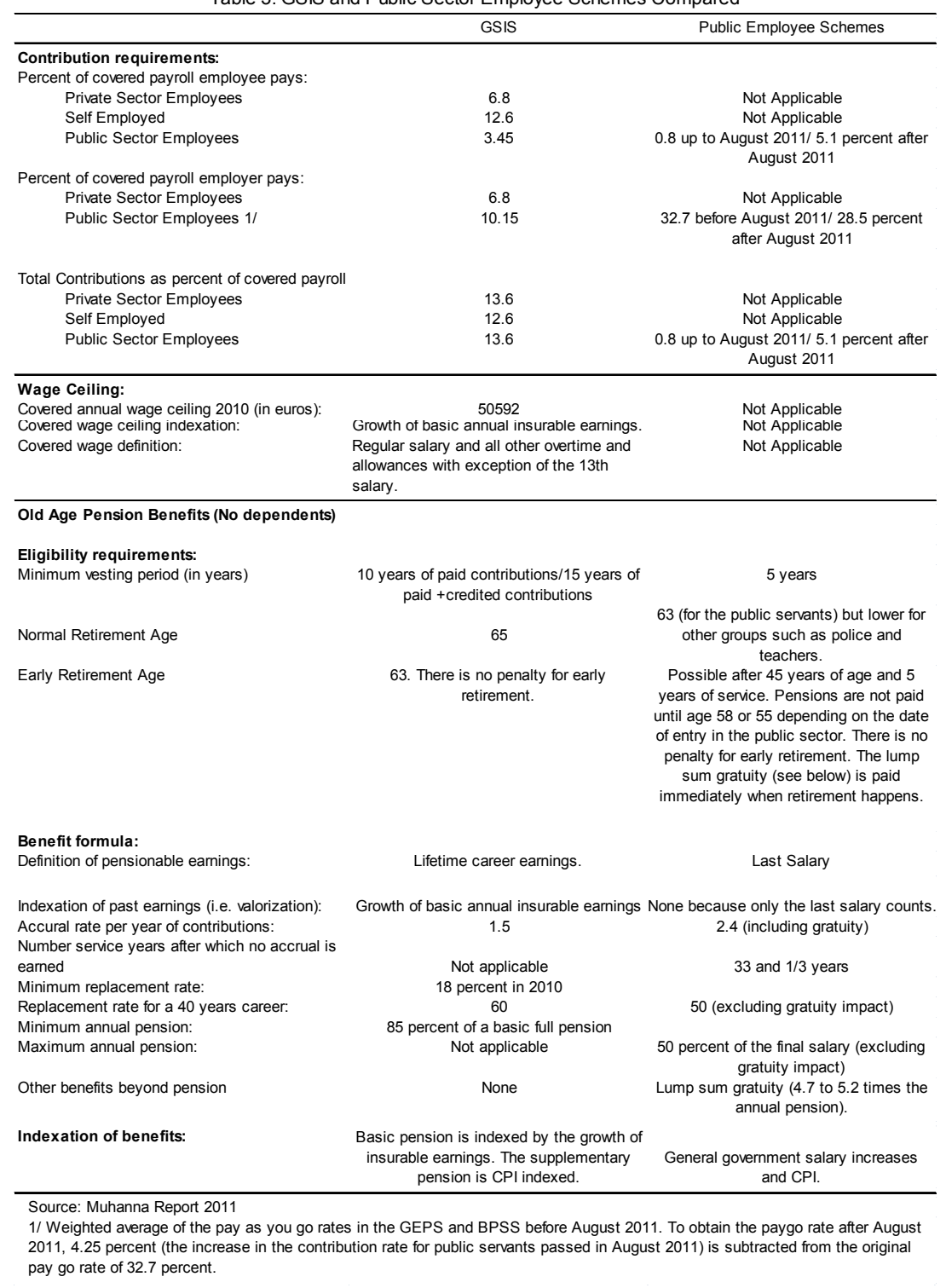

${ }^{6}$ Formally, public employees pay a 3.45 percent contribution rate to the GSIS and the government pays 10.15 as an employer contribution. 
11. The calculation of supplementary pension benefits is more generous than the one for private sector employees provided by GSIS (Table 3). Key differences are:

- The scheme's effective retirement age is lower. The effective retirement age is about 6 and one half years lower than the GSIS at 57 years of age. This is because early retirement is allowed from age 45 but the pension is frozen and will only be paid at the age of 55 ( 58 for government employees who joined the employer on or after 1 July, 2005) without any actuarial reduction of benefits. The mandatory retirement ages for civil servants are: 63 for the civil service, 60 for teachers, between 60 and 61 for police, and for the military it ranges between 52 and 60 depending on the position and rank.

- $\quad$ The pension is calculated on the final salary at an accrual rate that produces a retirement benefit equivalent to 50 percent of that salary after $331 / 3$ years of service.

- A large lump sum gratuity is paid immediately when an employee retires and is a multiple of the annual pension. The size of the multiple ranges from 4.7 if retirement happens at 60 years of age to 5.2 if retirement happens at age 63.

- $\quad$ The pension is adjusted for general salary increases in the central government and for inflation.

12. BPSS pension benefits are similar to those of GEPS. Benefits are provided under the same terms and conditions as for central government employees and the formula to compute the pension is also the same.

\section{The net cost of the GEPS/BPSS schemes to the government has been} increasing (Table 4). In 2010 benefit payments were 2.8 percent of GDP. These latter benefits imply an average pay as you go cost of 32.7 percent of the wage bill, far exceeding public employee's contributions of 0.8 percent of the wage bill before August 2011 and the 5.1 percent after that date.

Table 4. Net Cost of Pension Schemes for Public Employees

\begin{tabular}{|c|c|c|c|c|c|}
\hline \multicolumn{6}{|c|}{ (Percent of GDP) } \\
\hline & 2006 & 2007 & 2008 & 2009 & 2010 \\
\hline Contributions & 0.1 & 0.1 & 0.1 & 0.1 & 0.1 \\
\hline Benefits & 2.1 & 2.2 & 2.0 & 2.4 & 2.8 \\
\hline Pensions & 1.6 & 1.6 & 1.6 & 1.7 & 2.2 \\
\hline Public servants & 0.6 & 0.6 & 0.6 & 0.7 & 0.9 \\
\hline Teachers & 0.5 & 0.5 & 0.5 & 0.6 & 0.7 \\
\hline Police and fire department & 0.3 & 0.3 & 0.3 & 0.3 & 0.4 \\
\hline Cyprus Army-National Guard & 0.0 & 0.1 & 0.1 & 0.1 & 0.1 \\
\hline Widows and orphans & 0.1 & 0.1 & 0.1 & 0.2 & 0.2 \\
\hline Government officials & 0.0 & 0.0 & 0.0 & 0.0 & 0.0 \\
\hline Gratuities & 0.6 & 0.7 & 0.4 & 0.7 & 0.6 \\
\hline Public servants & 0.2 & 0.4 & 0.1 & 0.4 & 0.3 \\
\hline Teachers & 0.2 & 0.2 & 0.2 & 0.2 & 0.2 \\
\hline Police and fire department & 0.1 & 0.1 & 0.1 & 0.1 & 0.1 \\
\hline Cyprus Army-National Guard & 0.1 & 0.0 & 0.0 & 0.0 & 0.0 \\
\hline Government officials $1 /$ & 0.0 & 0.0 & 0.0 & 0.0 & 0.0 \\
\hline Net cost & -2.1 & -2.2 & -2.0 & -2.4 & -2.7 \\
\hline
\end{tabular}

14. The last reform of the schemes was in August 2011. The reform aimed at reducing the cost of the system to the government and improving equity with private sector employees. The main measures were an increase in the permanent contribution rate 
for public employees from 0.8 percent to 5.1 percent of the wage bill and the abolition of access to public sector schemes for new public sector workers. In addition, an additional temporary contribution on public employees and pensioners in the public sector was also imposed, based on their income.

\section{Main Issues}

\section{General Social Insurance Scheme}

15. The GSIS is expected to continue to run growing deficits in the coming years. The overall balance of the GSIS excluding government contributions and interest income is expected to continue deteriorating in 2012 and 2013 as a result of increased pension spending due to long term factors (see Table 5 and below). While the increase in the contribution rate in 2014 will temporarily reduce the deficit of the GSIS, the GSIS is expected to end the decade with deficits of about 1.5 percent of GDP. This differs significantly from status quo analysis from existing studies that incorporate the 2009 reforms which suggest no deficit until the 2040's. The difference with these studies arises mainly because of the exclusion of the government contribution and interest income as part of the revenues of the scheme.

Table 5. Projected Accounts of the Social Insurance Fund (Percent of GDP)

\begin{tabular}{|c|c|c|c|c|c|c|c|c|c|c|c|}
\hline & 2010 & 2011 & 2012 & 2013 & 2014 & 2015 & 2016 & 2017 & 2018 & 2019 & 2020 \\
\hline Total revenue & 5.9 & 6.0 & 6.0 & 6.1 & 6.6 & 6.6 & 6.7 & 6.7 & 6.8 & 7.3 & 7.4 \\
\hline Contribution from employees and employers & 5.8 & 5.8 & 5.9 & 5.9 & 6.4 & 6.5 & 6.5 & 6.6 & 6.6 & 7.1 & 7.2 \\
\hline Other current revenue & 0.2 & 0.2 & 0.2 & 0.2 & 0.2 & 0.2 & 0.2 & 0.2 & 0.2 & 0.2 & 0.2 \\
\hline Total expenditure & 6.3 & 6.5 & 6.8 & 7.0 & 7.4 & 7.6 & 7.8 & 8.0 & 8.3 & 8.5 & 8.8 \\
\hline Current expenditure & 6.3 & 6.5 & 6.8 & 7.0 & 7.4 & 7.6 & 7.8 & 8.0 & 8.3 & 8.5 & 8.8 \\
\hline Goods and services & 0.1 & 0.1 & 0.1 & 0.1 & 0.1 & 0.1 & 0.1 & 0.1 & 0.1 & 0.1 & 0.1 \\
\hline Transfers & 6.3 & 6.4 & 6.7 & 7.0 & 7.3 & 7.5 & 7.8 & 8.0 & 8.2 & 8.4 & 8.7 \\
\hline Unemployment benefits & 0.5 & 0.5 & 0.6 & 0.5 & 0.5 & 0.5 & 0.4 & 0.4 & 0.4 & 0.4 & 0.3 \\
\hline Benefits & 5.8 & 5.9 & 6.1 & 6.5 & 6.8 & 7.1 & 7.3 & 7.6 & 7.8 & 8.1 & 8.4 \\
\hline Old age and early retirement pensions & 5.3 & 5.4 & 5.6 & 5.9 & 6.2 & 6.4 & 6.7 & 6.9 & 7.1 & 7.4 & 7.6 \\
\hline Other benefits & 0.5 & 0.5 & 0.6 & 0.6 & 0.6 & 0.6 & 0.7 & 0.7 & 0.7 & 0.7 & 0.8 \\
\hline Capital expenditure & 0.0 & 0.0 & 0.0 & 0.0 & 0.0 & 0.0 & 0.0 & 0.0 & 0.0 & 0.0 & 0.0 \\
\hline Gross fixed capital formation & 0.0 & 0.0 & 0.0 & 0.0 & 0.0 & 0.0 & 0.0 & 0.0 & 0.0 & 0.0 & 0.0 \\
\hline Overall balance & -0.4 & -0.5 & -0.7 & -1.0 & -0.8 & -1.0 & -1.1 & -1.3 & -1.5 & -1.2 & -1.4 \\
\hline \multicolumn{12}{|l|}{ Memorandum items: } \\
\hline Overall balance including government contributions and interest income & 2.0 & 1.9 & 1.7 & 1.5 & 1.9 & 1.7 & 1.5 & 1.4 & 1.2 & 1.6 & 1.5 \\
\hline Government contributions & 1.8 & 1.8 & 1.9 & 1.9 & 2.0 & 2.0 & 2.1 & 2.1 & 2.1 & 2.3 & 2.3 \\
\hline Interest Income & 0.6 & 0.6 & 0.6 & 0.6 & 0.6 & 0.6 & 0.6 & 0.6 & 0.6 & 0.6 & 0.6 \\
\hline
\end{tabular}

Sources: Ministry of Finance; and IMF staff estimates

16. Spending on the GSIS is expected to accelerate markedly from 2040 onwards and will be among the highest in the Euro Area by 2050. Given demographic, macroeconomic, and labor market assumptions (see Box 2 in the Appendix) and the pension system parameters in the current legislation, the projection shows an increase in benefit expenditure of about 8 percent of GDP from 2010 to 2050. This compares unfavorably to increases in pension spending at the level of the OECD, which are expected to be around 3 percent of GDP between 2010 and 2050 (OECD 2011). On the 
revenue side, assuming the already legislated schedule of increases in the contribution rate and a wage bill that remains broadly constant as a share of GDP, this would imply a need for increased government transfers of about 5 percent of GDP by 2050. The accumulation of significant deficits by 2050 would generate an implicit pension liability close to 100 percent of GDP with a 4.5 percent discount rate ${ }^{7}$.

\begin{tabular}{|c|c|c|c|c|c|c|c|c|c|}
\hline & 2010 & 2015 & 2020 & 2025 & 2030 & 2035 & 2040 & 2045 & 2050 \\
\hline Total revenue & 5.9 & 6.6 & 7.4 & 7.8 & 8.3 & 8.7 & 9.2 & 9.2 & 9.2 \\
\hline Contribution from employees and employers & 5.8 & 6.5 & 7.2 & 7.7 & 8.1 & 8.6 & 9.0 & 9.0 & 9.0 \\
\hline Other current revenue & 0.2 & 0.2 & 0.2 & 0.2 & 0.2 & 0.2 & 0.2 & 0.2 & 0.2 \\
\hline Total expenditure & 6.3 & 7.6 & 8.8 & 10.1 & 11.1 & 11.6 & 12.2 & 13.0 & 14.3 \\
\hline Current expenditure & 6.3 & 7.6 & 8.8 & 10.1 & 11.1 & 11.6 & 12.2 & 13.0 & 14.3 \\
\hline Goods and services & 0.1 & 0.1 & 0.1 & 0.1 & 0.1 & 0.1 & 0.1 & 0.1 & 0.1 \\
\hline Transfers & 6.3 & 7.5 & 8.7 & 10.0 & 11.0 & 11.6 & 12.1 & 13.0 & 14.2 \\
\hline Unemployment benefits & 0.5 & 0.5 & 0.3 & 0.3 & 0.3 & 0.3 & 0.3 & 0.3 & 0.2 \\
\hline Benefits & 5.8 & 7.1 & 8.4 & 9.7 & 10.7 & 11.3 & 11.8 & 12.7 & 14.0 \\
\hline Old age and early retirement pensions & 5.3 & 6.4 & 7.6 & 8.8 & 9.8 & 10.3 & 10.8 & 11.6 & 12.7 \\
\hline Other benefits & 0.5 & 0.6 & 0.8 & 0.9 & 1.0 & 1.0 & 1.1 & 1.1 & 1.3 \\
\hline Capital expenditure & 0.0 & 0.0 & 0.0 & 0.0 & 0.0 & 0.0 & 0.0 & 0.0 & 0.0 \\
\hline Gross fixed capital formation & 0.0 & 0.0 & 0.0 & 0.0 & 0.0 & 0.0 & 0.0 & 0.0 & 0.0 \\
\hline Overall balance & -0.4 & -1.0 & -1.4 & -2.2 & -2.8 & -2.9 & -3.0 & -3.9 & -5.1 \\
\hline \multicolumn{10}{|l|}{ Memorandum items: } \\
\hline Overall balance including the government contribution and interest income & 2.0 & 1.7 & 1.5 & 0.7 & 0.2 & 0.2 & 0.2 & -0.8 & -2.1 \\
\hline Government contributions & 1.8 & 2.0 & 2.3 & 2.4 & 2.6 & 2.7 & 2.9 & 2.9 & 2.9 \\
\hline Interest Income & 0.6 & 0.6 & 0.6 & 0.6 & 0.5 & 0.4 & 0.3 & 0.2 & 0.1 \\
\hline
\end{tabular}

\section{The evolution of the finances can be explained by the following formula ${ }^{8}$ :}

$$
T=(D R * R R-C R) * W \quad(\text { Equation 1) }
$$

$\mathrm{T}=$ Government transfers as a share of GDP

$\mathrm{CR}=$ Contribution Rate

$\mathrm{DR}=$ Dependency Ratio (Number of pensioners/Number of contributors)

$\mathrm{RR}=$ Replacement Ratio (Average pension/average pensionable salary)

$\mathrm{W}=$ Covered wage bill as a share of GDP (Number of contributors*Average pensionable salary/GDP)

The formula states that the government transfer as a share of GDP that will be needed to finance the pension system will be larger the higher the dependency ratio, the higher the replacement rate and the lower the contribution rate, assuming all the rest constant.

\footnotetext{
${ }^{7}$ The implicit pension debt is the present value of all overall balance results for the GSIS between 2012 and 2050 computed assuming a certain discount rate. The 4.5 percent discount rate was used to be consistent with the one assumed by Muhanna (2011) for the schemes for public sector employees.

${ }^{8}$ This formula is derived from the budget constraint of the social security fund where transfers + contribution income + other income $=$ pension benefit expenditure + other benefit expenditure + administrative costs. Assuming for simplicity that other income, other benefit expenditure, and administrative costs are 0 , and carrying out some algebraic manipulations yields the formula above.
} 
17. A worsening DR is the main reason for the increased deficits of the SSF, followed by an increasing replacement ratio. Keeping RR, CR, and W at their 2010 values, and only allowing the system dependency ratio to worsen in line with the population projection, shows to what extent the worsening dependency ratio is responsible for the 5 percent of GDP increase in the transfer need/deficit by 2050 . This calculation shows that the deterioration of the dependency ratio could explain a 4.8 percent of GDP higher transfer need. A similar calculation for the replacement rate explains an increasing transfer need of 1.2 percent of GDP'. The result thus shows that the increase in the transfer need is expected to occur mainly due to the impact of ageing (i.e. declining fertility and mortality rates) on the dependency ratio but also due to the impact of scheme maturation (i.e. there will be more workers completing a minimum number of working years to qualify for a benefit from the supplementary part of the GSIS and retiring with a higher number of years of contributions at retirement) on the replacement rate.

\section{Current scheme parameters are generous when measured in terms of a rate} of return on contributions and compared to long term market returns. Given current and past scheme parameters, a recent actuarial study (Muhanna (2011)) has estimated a nominal internal rate of return on contributions of about 13 percent for current pensioners. Assuming a long term rate of inflation around 2 percent in line with ECB targets, this implies that contributions would need to be invested in a market portfolio that could generate a return exceeding 10 percent in real terms to be comparable to a real rate of return paid by the national pension scheme. However, achieving such high real returns in the market for long periods is highly unlikely as real long term returns on a market portfolio have averaged around 3 to 4 percent (OECD 2011, Muhanna (2011)).

\section{Several pension scheme parameters contribute to the high internal rates of return for current pensioners:}

- An effective retirement age below the standard age due to early retirement. Between 65 and 70 percent of all new retirees retire at age 63, making the effective retirement age around 63.6 given the absence of actuarial pension reductions for early retirement which are common in many systems with early retirement (Appendix Table 1).

- Increasing life expectancy at retirement. This means an increasing retirement period over which pensions will need to be paid with the same contribution period as life expectancy at retirement ( 65 years) is expected to increase on average

\footnotetext{
${ }^{9}$ The increase in the transfer need due to a worsening dependency ratio and an increasing replacement rate, which add up to 6 percentage points of GDP, is partially offset primarily by the impact of an increasing contribution rate. This leads to an overall impact of a 5 percent of GDP additional transfer need.
} 
3.1 years for men and 3.6 years for women in the OECD between years 2010 and 2050 (Appendix Table 2).

- $\quad$ A relatively generous indexation scheme for pensions in payment. The indexation scheme is de facto a weighted average of wage and price indexation where the weights are the shares of the basic (about 40 percent in 2010) and supplementary pension (about 60 percent in 2010) respectively. Most OECD countries with earnings related schemes index their pensions in payment to prices, while some use wages in several cases subject to sustainability constraints, and only a few index using a combination of wages and prices or wages only (Appendix Table 3).

- $\quad$ Relatively low contribution rates for the provided level of benefits. While benefits in Cyprus for a full career worker (64.5 percent replacement rate) are somewhat above the OECD comparable average gross replacement rate (57 percent), the overall contribution rate for pensions that employees and employers pay at close to 13 percent is significantly lower than in most other OECD countries that provide similar gross replacement rates (Appendix Table $4)^{10}$.

- A management of pension system reserves that has not followed international good practices. Reserves have not been invested in a well diversified portfolio of assets subject to clear investment guidelines for risk, return, and liquidity. In addition, the function of reserves has not been to help absorb shocks in benefit payments and contributions and/or finance future pension payments as the pension system reaches its maturity as is standard in partially funded systems.

\section{Pension Schemes for Public Employees}

20. The pension schemes for public employees are costly and their cost will continue to increase if they are not reformed further. In 2010, 2.6 percentage points of GDP were spent on pensions net of contributions for public sector workers. This compares unfavorably to an average of 2 percent of GDP in OECD countries (Palacios and Whitehouse 2006). Without reforms the net pension cost would have increased by about 2 percentage points of GDP by 2050. The August 2011 permanent reforms were steps in the right direction (text chart). They are expected to bring down the net cost by 0.4 percent of GDP per year starting in 2012 and roughly maintain current expenditure levels by 2050 as the number of retirees start to decline as a result of closing the scheme to new government workers. However, spending on pensions for public sector employees

\footnotetext{
${ }^{10}$ The definition of a full career worker in OECD (2011) is a worker had a 45 years career. This definition was used to be able to compare the replacement rate that the Cypriot system provides at retirement for a full career worker that earns the average salary with that of other OECD countries.
} 
will still be expected to increase for the next two decades given that retirees during this time period will be already existing contributors ${ }^{11}$.

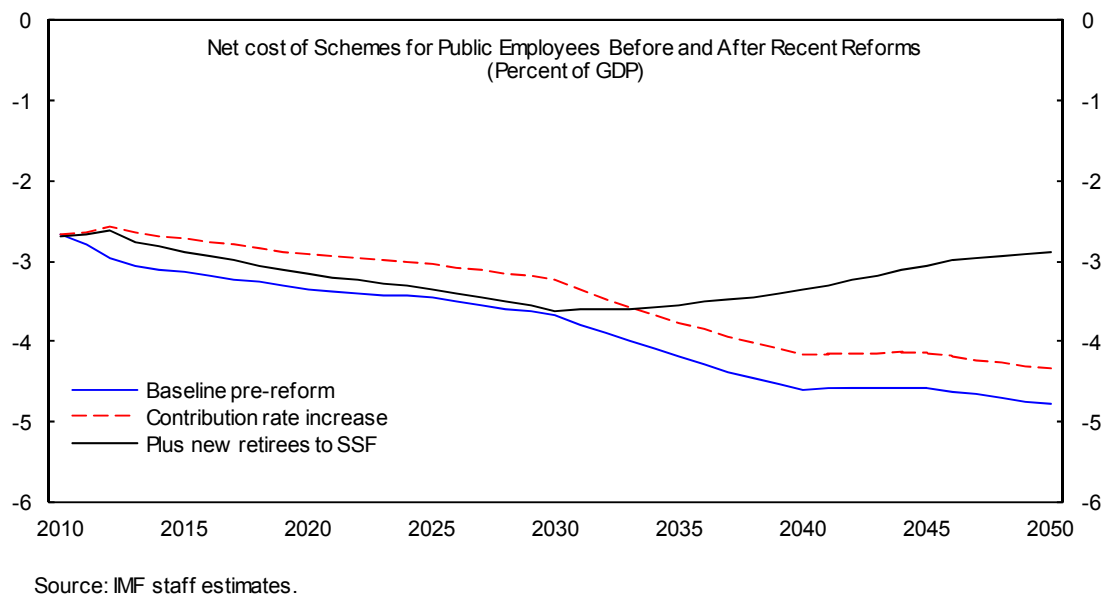

21. Beyond similar ageing forces that are operating for the GSIS, several factors are contributing to the continued fiscal burden of the public pension scheme and inequities with the private sector:

- Public sector workers continue pay low contributions with respect to the cost of the benefits. The permanent contributions they pay even after the reform are about 5 percent of salaries while the cost of providing the benefits in 2011 is expected to be close to 33 percent of salaries (Table 3).

- The benefit formula is relatively generous and creates distortions. Basing the pension on the last salary, which is typically the highest in the career of a public employee and is thus not representative of career earnings, provides an incentive to maximize earnings as retirement approaches, including through promotions before retirement. In addition, it creates inequities by discriminating in favor of individuals whose earnings rise rapidly over their career. Moreover, without including the impact of the gratuity, Muhanna (2011) suggests that the replacement rate over the final salary is estimated to be between 20 and 40 percent higher than the one in the GSIS, depending on salary levels.

- The lump sum benefit at retirement increases considerably further the replacement rate. After including the impact of the lump sum benefit by converting it into a monthly pension, the replacement rate over the final salary is between 45 and 65 percent higher than in the GSIS, with replacement rates of close to 80 percent of the final salary for average earners.

\footnotetext{
${ }^{11}$ For simplicity, the impact of temporary measures adopted in August 2011 is excluded given that these measures expire in 2013.
} 
- Special regimes for different groups of employees including more favorable retirement ages. Teachers, the police, and the army constitute the bulk of public employees in government and these groups are subject to lower retirement ages than civil servants and private sector employees. Special and more generous pension rules also apply to state officials (including mainly senior government officials, parliamentarians, and the public and education service commissions).

- Early retirement rules which allow retirement many years earlier than the statutory retirement age without any actuarial deduction. As a result, the effective retirement age is about 57 and pensions are paid for more years while contributions are received for fewer at a cost to the budget.

- Indexation using growth of public salaries. This provision is not only more generous than for private sector employees but also exposes the budget to large increases in pension benefits automatically if large ad hoc wage increases are provided as was the case for example in 2009.

22. Moreover, comparisons with other public service pension schemes in advanced countries also point to the generosity of some parameters:

- The statutory retirement age at 63 is relatively at the low end of the distribution. While schemes of public employees tend to have lower retirement ages than national schemes such as the GSIS, many schemes have retirement ages of 65 years and above (Appendix Table 5).

- Benefits are on the high end of the distribution. After taking into account the impact of the use of the final salary as the definition of earnings and the lump sum gratuity, the replacement rate for the average earner close to 80 percent of the final salary combined with the possibility of achieving this in 33.3 years implies an accrual rate close to 2.5 percent per year. (Appendix Table 6).

- Indexation is also on the generous side. A majority of countries index pensions in payments at least partially with the CPI. (Appendix Table 7).

\section{Reform Options}

\section{General Social Insurance Scheme}

23. Pension reform is needed to restore the long term financial sustainability of the scheme and to address the growing cash deficits in the coming years. Reforms are best implemented early so that abrupt adjustment to parameters are avoided. Gradual adjustments have the advantage of making reform more equitable as the burden of adjustment can be spread across many generations and workers have more time to adjust their work and savings decisions to the new parameter levels. As suggested by equation 1, main reform levers are: (1) retirement age increases (affect primarily DR), reduction in 
benefits (affects RR), less generous indexation (affects RR), and increases in the contribution rate $(\mathrm{CR})$.

\section{Several specific reform options are discussed below in line with what other}

OECD countries have done to address similar issues. These options should be taken only as illustrative of the possibilities of gradual reforms and their impact. Different combinations of measures could have a similar impact on the overall finances of the scheme and preferences on the mix have varied across countries. However, given the already considerable revenue to GDP levels in Cyprus and that contribution rate increases were already decided in 2009 to bring contribution levels close to the current OECD average by 2039, raising the contribution rate levels beyond the final level targeted by the planned increases could be counterproductive. This could unduly increase labor taxes with an adverse competitiveness impact on the economy and provide added incentives to informal economic activity. Moreover, the causes of the expected deterioration of GSIS finances also suggest that a combination of reforms that place a strong emphasis in extending the working life and adjusting down the level of benefits should be preferred.

\section{The adoption of all of these reform options would eliminate the implicit} pension debt through 2050. GSIS projected finances assuming all reforms are implemented are shown in the text chart below as well as the cumulated impact of the different measures with respect to the baseline, which includes the already legislated increases in the contribution rate for employees and employers in Table 2.

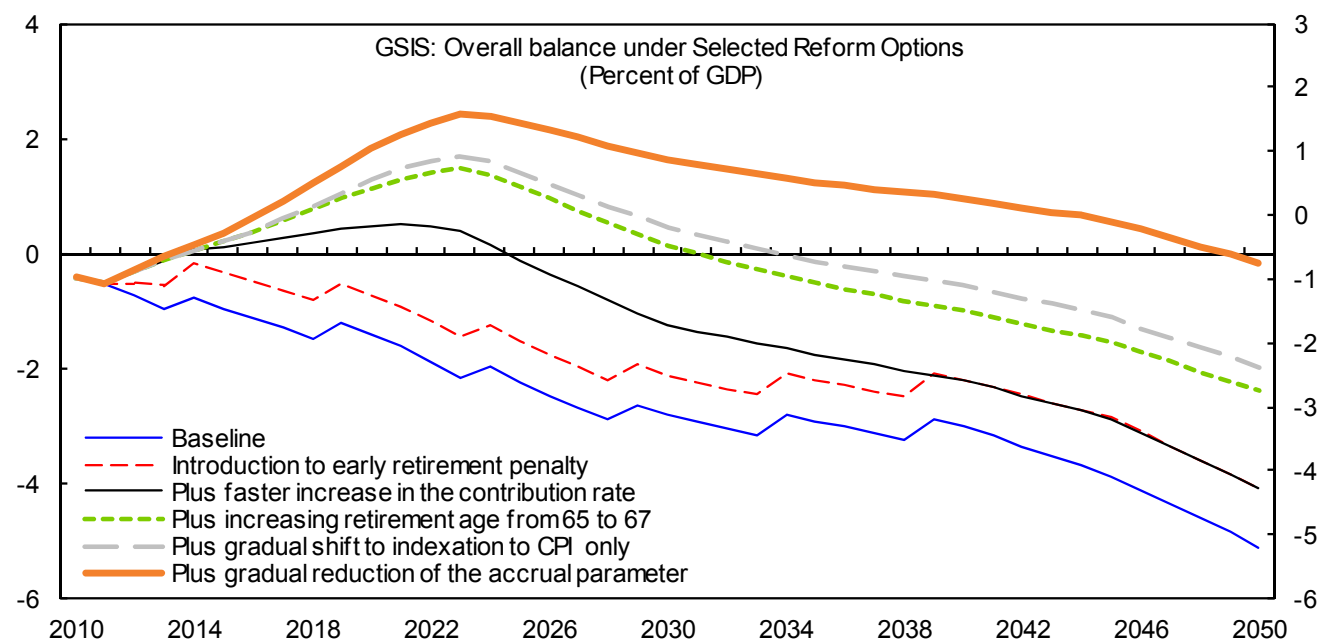

\section{Benefit policies}

Source: IMF staff estimates.

26. Increase the incentives to postpone retirement. This can be achieved by introducing an actuarially fair early retirement penalty for each year of early retirement to ensure that the cost of early retirement to the scheme is fully internalized by workers. As shown in Appendix Table 1, actuarial reductions in OECD countries vary, but in those 
where the reduction is considered effective in providing adequate incentives, the values range between 6 to 7 percent pension reduction per year of early retirement. Assuming this measure would lead to an increase in the effective retirement age to 65 in three years if implementation starts in 2012, the GSIS deficit would be reduced on average by 0.8 percent of GDP through 2050 .

\section{Increase gradually the retirement age from 65 years to 67 years and from} then on automatically on the basis of life expectancy at retirement. If the retirement age is increased by 2 years in 10 years starting in 2015, the savings from the retirement age increase from 65 to 67 would reduce the GSIS deficit by 1.1 percentage points of GDP on average through 2050. At the same time, incorporating in the legislation an automatic adjustment provision that would be activated once the effective retirement age reaches 67 years will help depoliticize the adjustment of this critical pension parameter when needed and guard against faster than anticipated increases in life expectancy which have been the norm in the past (OECD 2011).

\section{Lower the accrual rate to make benefits more in line with most OECD}

countries. To avoid an abrupt change in the benefit formula, the adjustment of the accrual rate could be phased in gradually. For example, a phased reduction of the accrual rate in 14 years from 1.5 to 1.2 percent, starting in 2012, would partially offset the impact of system maturation and thus create savings which, as illustrated in Figure 2 above, would reduce the GSIS deficit on average by 1.1 percentage points of GDP through 2050 .

29. Index pension benefits fully by prices. A majority of OECD countries have chosen this approach as Appendix Table 3 suggests, and an important reason for this is affordability. However, by preserving the purchasing power of pensions, price indexation allows for the maintenance of pensioners' standard of living at retirement defined as the purchasing power of the pension. For example, given an assumed wage growth-inflation differential, a phased shift to CPI indexation in 9 years could lead to an average reduction in the deficit of 0.3 percent of GDP on average through 2050.

\section{Revenue policies}

30. Increase the contribution rate more frequently with smaller steps to reach the currently planned level of contributions from employees and employers for 2039 faster. Achieving the final contribution rate levels targeted by the 2009 reform faster would bring contributions more in line with the level of benefits provided by GSIS and with contribution rates in other OECD countries. It would also help reduce current deficits and give time for other measures that affect new pensioners (e.g. measures that help increase the effective retirement age) and thus take longer to impact the system finances to have their full impact. For example, increasing the contribution rate by 0.5 percentage points per year starting in 2012 until reaching 19.6 percent in 2023 would increase revenues on average by an estimated 0.6 percent of GDP through 2050. 


\section{Investment policies}

\section{Review the management of surpluses and reserves to make it consistent with} international good practices. The reforms discussed above could create cash surpluses through almost the end of the projection period and would therefore lead again to a considerable accumulation of reserves (text chart). To ensure these new reserves are invested and used to support the payment of pensions, investment guidelines should be adopted to facilitate the investment of the newly available funds into an internationally diversified portfolio of assets ${ }^{12}$. The guidelines should include such items as restrictions on the share of assets that can be held in any one company or country, a requirement that assets be managed by competent professionals selected through a transparent and competitive bidding process, restrictions on the amount of costs that can be incurred in managing the assets (e.g., less than 0.5 percent of assets) and the types of investments that are permissible (e.g. highly leveraged and other risky investments should be prohibited). Investments and investment returns should be publicly disclosed, benchmarked against an appropriate market portfolio, and independently audited.

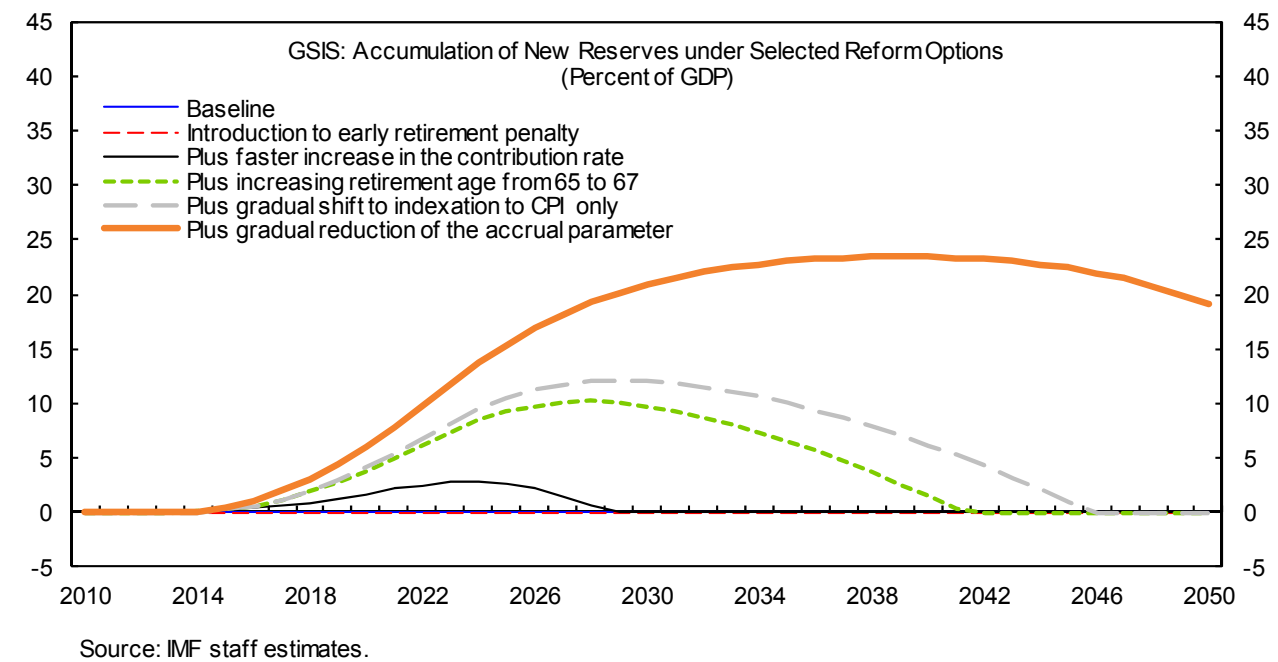

\section{Schemes for Public Employees}

\section{Deeper reforms will be needed to prevent the large cost from pension} schemes for public employees from persisting for decades. While the August 2011 permanent measures were an important first step at reform, the government will still be

\footnotetext{
${ }^{12}$ It is important to indicate that only newly created reserves on the basis of surpluses created by reforms of the GSIS would be invested in private assets. Existing reserves, i.e. government paper, would not be invested in private assets as this would require conversion of the government paper into liquid assets and would thus generate additional financing needs to the government.
} 
incurring high and escalating costs under realistic assumptions in the coming decades. Moreover, these schemes would remain significantly more generous than the GSIS, generating significant inequities not only with the private sector but also between current government employees and the new ones who will retire under the GSIS. Moreover, such stark inequities could threaten the sustainability of the reform risking partial or total reform reversals in the future.

\section{Reforms should aim at making the residual public sector pension schemes} self financing over a transitional period and ensure that benefits for public sector workers converge to those of the reformed GSIS. Given the current generosity of benefits and low retirement ages with respect to the GSIS scheme and in an international context, and that many workers paid only minimal contributions for these benefits for a significant part of their career, increases in the effective retirement age and a reduction in benefits for public employees who will still receive their pensions under the current schemes seem to be important options that would improve fairness with new employees and the private sector. Benefits should at least be reduced to GSIS levels and track them once GSIS levels are achieved. Remaining actuarial imbalances after these benefit reductions should be matched by employee contributions that fully finance the cost of the reformed benefits. The transitional period would allow workers close to retirement to be treated more favorably than younger employees, given that the former are at the end of their careers and have fewer options to adapt to the change in their retirement benefits.

\section{Options that would contribute to achieving the above goals gradually include:}

- Increasing the effective retirement age. This could be achieved by converging to a uniform retirement age policy for most public sector employees equal to the one for the GSIS and exempting from this principle only those groups for which there are well defined reasons accepted internationally to justify early retirement. This includes setting the same statutory retirement age as the GSIS and the same early retirement rules including the introduction of an early retirement penalty. In addition, special regimes for specific groups should gradually be phased out ${ }^{13}$.

- $\quad$ Shifting indexation from public wages to CPI for pensions in payment. For example, given assumptions for the public wage growth-inflation differential and a linear phasing over a 5 year period starting in 2012, this would save 0.1 percent of GDP on average through 2050. The effective de-linking of public sector salary increases that this measure generates also helps protect pension finances from large ad-hoc wage increases such as those observed in 2009.

\footnotetext{
${ }^{13}$ Fiscal impact estimates for this measure were not computed given that a distribution showing the number of pensioners in public schemes of a given age and their average pensionable salaries was not available.
} 
- $\quad$ Reducing gradually the lump sum benefit at retirement until eliminating it. For example, assuming this measure is phased in linearly over 10 years starting in 2012, this would save 0.5 percent of GDP on average through 2050.

- Increasing the number of years over which pensionable earnings are calculated and indexing wage histories to an index of average pensionable earnings. Common international practice is to calculate average earnings over 25 to 40 years, with wages from past years typically converted into current euros using an index of the average pensionable wage of contributors. Assuming that this generates an additional 30 percent cut in the replacement rate on average, in line with Muhanna (2011) estimates, if this is phased in over 10 years starting in 2012, savings would amount to less than 0.1 percent of GDP on average through 2050.

- Increasing further the contribution rate for public workers. Increasing the contribution rate from 5 percent to 10 percent in 10 years starting in 2013 would save on average 0.1 percent of GDP through 2050.

Figure 4 below illustrates the cumulative impact of some of the options above in addition to the permanent measures adopted in August 2011. It is important to note that since most measures affect new retirees, impacts shown in Figure 4 are smaller primarily at the end of the projection period given the limited number of new retirees that will remain by then. Combining these measures with an increase in the effective retirement age would result in larger impacts. This is because, all the rest constant, the number of contributors would be higher and retiree growth would slow. This underscores the importance of increasing the effective retirement age to improve the finances of the public pension schemes.

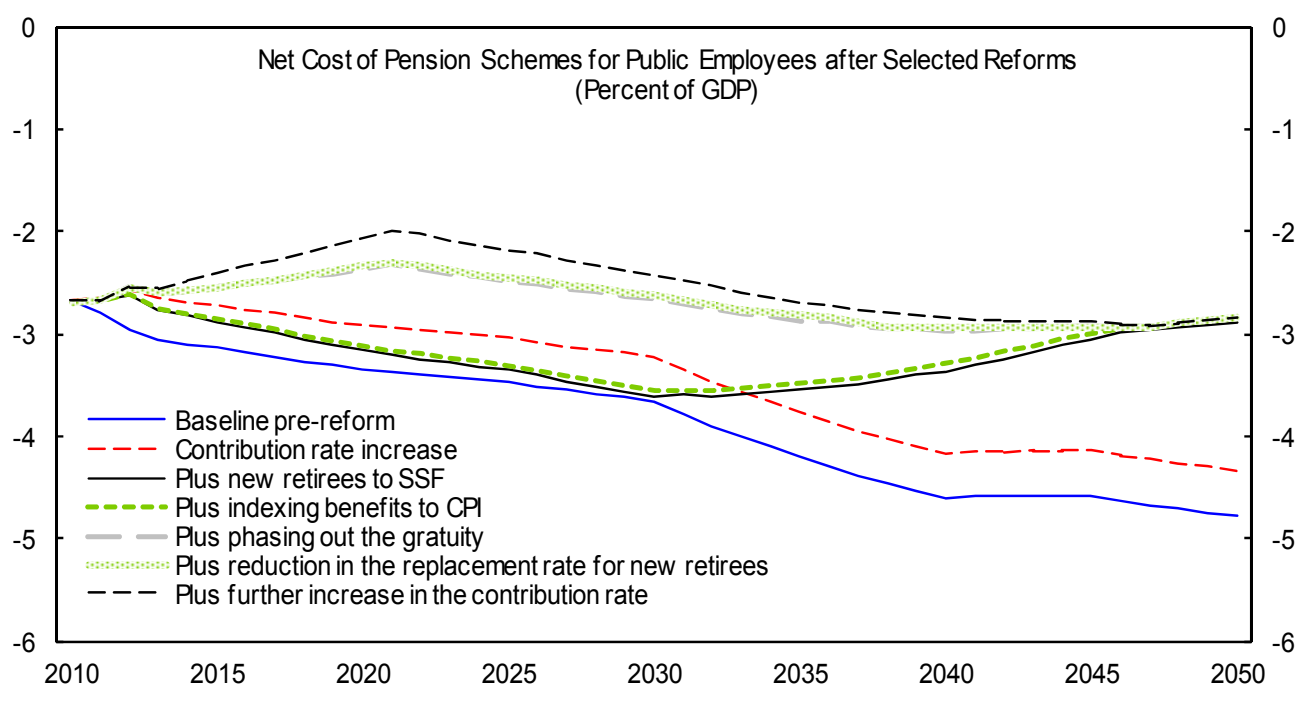

Source: IMF staff estimates. 


\section{E. Conclusion}

35. Reforming the GSIS and pension schemes for public employees is key to reduce growing public pension costs and address long term fiscal challenges. Now is the time to initiate reform to ensure that the financial position of both systems is sustainable. The policy choice with unsustainable pension finances is not between reform or no reform but between a gradual and equitable reform shared across many generations of contributors and pensioners or a more abrupt and inequitable disruption if reforms are postponed until the mounting costs demand immediate action.

\section{References}

European Commission (2009), "Pension schemes and pension projections in the EU-27 Member States-2008-2009” Occasional Paper Series 56, Volumes I, II, and III.

European Commission (2009), "The 2009 Ageing Report: Economic and Budgetary Projections for EU-27 Member States (2008-2060)”, Main Report and Statistical Annex.

European Commission (2010), "Progress and key challenges in the delivery of adequate and sustainable pensions in Europe" Occasional Paper Series 71, Main Report and Annexes to the Main Report.

Kontolemis, Zenon, Matsi, Maria, and Stavrakis, Costas (2008) "Cyprus: Pension Fiche for the Ageing Working Group of the EPC", Ministry of Finance and Ministry of Labor and Social Insurance of Cyprus.

Muhanna and Company (2011), "Actuarial Study for the Computation of the Cost of Pension Benefits in the Public and Wider Public Sector" Reports 2 A, 2B, 2C, 2D and $2 \mathrm{E}$.

OECD (2011), "Pensions at a Glance 2011: Retirement-Income Systems in OECD and G20 Countries" OECD Publishing.

Palacios, Robert and Whitehouse, Edward (2006) "Civil service Pension Schemes Around the World", Social Protection Discussion Paper 602, The World Bank. 


\section{Appendix}

\section{Box 1. Old Age Pension GSIS Formulas}

The basic annual old-age pension is calculated as follows:

(60\% x (Basic Insurance Points x Annual Basic Insurable Earnings in the retirement year)) / (Insurance Period up to the $63^{\text {rd }}$ or $65^{\text {th }}$ birthday)

The 60 percent coefficient in the formula is increased to $80 \%$ for a beneficiary with one dependant, to $90 \%$ for a beneficiary with two dependants, and to $100 \%$ for a beneficiary with three dependants.

The supplementary annual pension is calculated as follows:

\section{5\% x (Supplementary Insurance Points x Annual Basic Insurable Earnings in the year of retirement)}

The total pension is the sum of the basic and the supplementary pensions. The total pension cannot fall below a minimum of $85 \%$ of the basic pension that would be paid to the beneficiary if he had full insurance in the basic part of the plan (i.e. if he had contributed during a full working career with a salary equivalent to the basic insurable earnings).

To illustrate the calculation, consider the case of an insured aged 63 that requests a pension in 2011 and meets the criteria for early retirement and the following information is given:

The insured has paid contributions as of his $24^{\text {th }}$ birthday

The insured has earned or been credited with 47 basic insurance points ( 39 from paid contributions and 8 from credited contributions) and 76 supplementary insurance points (approximately 2 for each year of work). This latter fact means that his salary was approximately 3 times the basic insurable earnings during his career.

The level of annual basic insurable earnings is equal to $€ 8,435$.

He has no dependents.

Then, the total annual pension is calculated as follows:

Annual Basic Pension $=60 \% * 47 * 8,435 / 47=€ 5,060$

Annual Supplementary Pension $=1.5 \% * 76 * 8,435=€ 9,616$

Total Annual Pension $=€ 5,060+€ 9,616=€ 14,676(€ 1,129$ per month $)$

Note that the number 47 in the denominator corresponds to the period of insurance which is calculated as the difference between $5 / 10 / 64$ and the $63^{\text {rd }}$ year of age. 


\section{Box 2. Underlying Data Assumptions for Projections}

\section{General Social Insurance Scheme}

Demographic Assumptions: The latest population projection available from Eurostat's website for Cyprus was used to derive the working age population and retirement age population. Given that the population data is available in 5 year intervals, a simple linear interpolation was used to annualize it.

Macroeconomic Assumptions: Projections for real GDP growth and average HIPC inflation through 2016 are as in the Selected Economic Indicators Table of the Staff Report (Table 1). After reaching 3 percent in 2016, real growth declines gradually to 2.5 percent in 2020 and, subsequently, to 1.8 percent by 2050 in line with projections provided by the Ministry of Finance for the Actuarial Review of the Schemes for Public Employees in the Public Sector. With respect to average inflation, it converges to 2 percent after 2016 and stays constant at this level in line with the European Central Bank (ECB) inflation target.

Labor market Assumptions: These assumptions follow broadly the ones published in the 2010-2014 Stability Program of the Republic of Cyprus. The total labor force participation rate is expected to increase from about 74 percent in 2010 to close to 80 percent due expected increases in female labor force participation. The unemployment rate projection is as in Table 1 of the Staff Report until 2016. After 2016, the unemployment rate continues its decline to slightly above 5 percent in 2020 and from then on continues to decline to about 4 percent in 2050. Employment is determined endogenously given the demographic assumptions, the labor force participation rate assumption, and the unemployment rate assumption. Labor productivity growth is derived from the real GDP growth projection and employment growth.

\section{Pension Schemes for Public Employees}

The pre-reform baseline scenario in Figure 1 is built using in most cases the same assumptions of the baseline scenario in Muhanna (2011). This includes 1.5 percent general salary increase each year, the same public employment growth path, the same mortality implied in the projections of the number of contributors and pensioners, and the same evolution of the average replacement rate.

The main assumption differences relate to macroeconomic assumptions. Real GDP growth and inflation in 2011-2016 are assumed to behave as in Table 1 of the Staff Report and long term inflation is assumed to be 2 percent instead of the 2.5 percent assumed in Muhanna (2011). These changes were made to ensure consistency with the macroeconomic framework for 2011-2016 and to have the same macroeconomic assumptions applied to the projections of both schemes. 
Appendix Table 1. Actuarial Penalties for Early Retirement 1/

\begin{tabular}{|c|c|c|c|}
\hline Country & Reduction & Country & Reduction \\
\hline \multirow[t]{2}{*}{ Australia } & $\cdots$ & Japan & $6.0 \%$ \\
\hline & $\frac{\ldots}{42 \%}$ & Korea & $6.0 \%$ \\
\hline \multirow{2}{*}{$\begin{array}{l}\text { Austria } \\
\text { Belgium }\end{array}$} & $4 . \angle \%$ & Luxembourg & \\
\hline & & Mexico & $\begin{array}{l}\cdots \\
\cdots\end{array}$ \\
\hline Canada & $7.2 \%$ & Netherlands & $\ldots$ \\
\hline \multirow{2}{*}{ Chile } & $\ldots$ & New Zealand & \\
\hline & $\ldots$ & & $3.8-4.7 \%$ \\
\hline Czech Republic & $5.3 / 8.9 \%$ & Norway & \\
\hline Denmark & $\cdots$ & Poland & $\cdots$ \\
\hline \multirow{2}{*}{ Estonia } & $\cdots$ & Portugal & $4.0-6.0 \%$ \\
\hline & $\ldots$ & & $6.5 \%$ \\
\hline \multirow{2}{*}{ Finland } & & Slovak Republic & \\
\hline & $0 / 7.2 \%$ & Slovenia & $1.2-3.6 \%$ \\
\hline \multirow{2}{*}{ France } & $0 / 5.0 \%$ & Spain & $6.0-7.5 \%$ \\
\hline & $4.0-7.0 \%$ & & \\
\hline Germany & $0 / 3.6 \%$ & & $4.1-4.7 \%$ \\
\hline \multirow{2}{*}{ Greece } & $0 / 6.0 \%$ & Sweden & \\
\hline & & & $4.50 \%$ \\
\hline \multirow{2}{*}{ Hungary } & $3.6 \% / 4.8 \%$ & Switzerland & $2.90 \%$ \\
\hline & & Turkey & $\ldots$ \\
\hline Iceland & $7.0 \%$ & United Kingdom & \\
\hline $\begin{array}{l}\text { Ireland } \\
\text { Israel }\end{array}$ & $\ldots$ & United States & $5.0 / 6.7 \%$ \\
\hline $\begin{array}{l}\text { Italy } \\
\text { Cyprus }\end{array}$ & $2.3-2.9 \%$ & & \\
\hline
\end{tabular}

Source: OECD, Pensions at a Glance 2011.

$1 /$ Some countries have more than one component in their pension system and thus may have more than one set of actuarial penalties such as France. 
Appendix Table 2. Life Expectancy at Age 65

\begin{tabular}{|c|c|c|c|c|c|c|}
\hline & \multicolumn{3}{|c|}{ Women } & \multicolumn{3}{|c|}{ Men } \\
\hline & $2005-10$ & $2045-50$ & $\begin{array}{l}\text { Difference } \\
2005-2050\end{array}$ & $2005-10$ & $2045-50$ & $\begin{array}{l}\text { Difference } \\
2005-2050\end{array}$ \\
\hline Japan & 23.33 & 27.30 & 4.0 & 18.10 & 21.28 & 3.2 \\
\hline France & 22.17 & 25.53 & 3.4 & 17.61 & 21.15 & 3.5 \\
\hline Switzerland & 21.64 & 25.19 & 3.5 & 18.37 & 21.97 & 3.6 \\
\hline Italy & 21.47 & 25.08 & 3.6 & 17.53 & 20.51 & 3.0 \\
\hline Australia & 21.42 & 24.89 & 3.5 & 18.15 & 21.37 & 3.2 \\
\hline Belgium & 20.32 & 24.80 & 4.5 & 16.50 & 20.16 & 3.7 \\
\hline Spain & 21.35 & 24.74 & 3.4 & 17.33 & 21.02 & 3.7 \\
\hline Iceland & 20.71 & 24.42 & 3.7 & 18.36 & 21.44 & 3.1 \\
\hline Canada & 20.93 & 24.39 & 3.5 & 17.73 & 21.04 & 3.3 \\
\hline Finland & 20.44 & 24.26 & 3.8 & 16.24 & 19.43 & 3.2 \\
\hline Israel & 20.25 & 24.13 & 3.9 & 17.82 & 21.13 & 3.3 \\
\hline Norway & 20.45 & 24.08 & 3.6 & 17.18 & 20.48 & 3.3 \\
\hline Austria & 20.16 & 24.02 & 3.9 & 16.88 & 20.69 & 3.8 \\
\hline Korea & 20.19 & 24.02 & 3.8 & 15.90 & 18.97 & 3.1 \\
\hline Germany & 20.21 & 23.97 & 3.8 & 16.55 & 19.90 & 3.4 \\
\hline New Zealand & 20.44 & 23.86 & 3.4 & 17.58 & 20.82 & 3.2 \\
\hline Ireland & 20.10 & 23.82 & 3.7 & 16.51 & 19.64 & 3.1 \\
\hline Sweden & 20.59 & 23.79 & 3.2 & 17.35 & 20.70 & 3.3 \\
\hline Slovenia & 19.77 & 23.68 & 3.9 & 14.90 & 18.50 & 3.6 \\
\hline Luxembourg & 20.06 & 23.67 & 3.6 & 16.24 & 19.93 & 3.7 \\
\hline OECD34 & 19.88 & 23.52 & 3.6 & 16.36 & 19.47 & 3.1 \\
\hline United Kingdom & 19.80 & 23.43 & 3.6 & 16.55 & 19.57 & 3.0 \\
\hline United States & 20.49 & 23.29 & 2.8 & 17.32 & 19.45 & 2.1 \\
\hline Greece & 18.54 & 23.29 & 4.7 & 16.62 & 19.49 & 2.9 \\
\hline Portugal & 19.71 & 23.25 & 3.5 & 15.81 & 18.88 & 3.1 \\
\hline Netherlands & 19.94 & 23.16 & 3.2 & 16.78 & 20.20 & 3.4 \\
\hline EU27 & 19.17 & 22.90 & 3.7 & 15.45 & 18.59 & 3.1 \\
\hline Chile & 20.33 & 22.90 & 2.6 & 17.04 & 18.64 & 1.6 \\
\hline Denmark & 19.31 & 22.62 & 3.3 & 15.97 & 18.83 & 2.9 \\
\hline Argentina & 18.93 & 22.33 & 3.4 & 14.68 & 17.43 & 2.8 \\
\hline Czech Republic & 17.60 & 22.05 & 4.4 & 14.02 & 17.69 & 3.7 \\
\hline Brazil & 18.71 & 21.93 & 3.2 & 16.23 & 18.05 & 1.8 \\
\hline Poland & 18.35 & 21.82 & 3.5 & 14.14 & 16.80 & 2.7 \\
\hline Mexico & 18.86 & 21.68 & 2.8 & 16.83 & 18.76 & 1.9 \\
\hline Estonia & 17.94 & 21.49 & 3.5 & 13.24 & 15.89 & 2.6 \\
\hline Slovak Republic & 17.22 & 21.07 & 3.9 & 13.29 & 16.32 & 3.0 \\
\hline Hungary & 16.90 & 20.70 & 3.8 & 12.87 & 15.82 & 2.9 \\
\hline China & 16.75 & 20.14 & 3.4 & 14.62 & 17.10 & 2.5 \\
\hline Saudi Arabia & 15.49 & 19.79 & 4.3 & 13.55 & 16.22 & 2.7 \\
\hline Indonesia & 14.70 & 19.20 & 4.5 & 13.06 & 15.68 & 2.6 \\
\hline Turkey & 15.03 & 19.15 & 4.1 & 13.01 & 15.42 & 2.4 \\
\hline Russian Federation & 15.41 & 18.64 & 3.2 & 11.85 & 14.21 & 2.4 \\
\hline India & 14.44 & 17.40 & 3.0 & 13.04 & 15.38 & 2.3 \\
\hline South Africa & 14.40 & 16.50 & 2.1 & 11.01 & 12.94 & 1.9 \\
\hline
\end{tabular}

Source: OECD, Pensions at a Galance 2011. 
Appendix Table 3. Pension Indexation Practices in National Pension Schemes

\begin{tabular}{lrlr}
\hline Country & & Country & \\
\hline Australia & $\ldots$ & Japan & $\mathbf{p}$ \\
Austria & $\mathrm{d}$ & Korea & $\mathbf{p}$ \\
Belgium & $\mathbf{p}$ & Luxembourg & $\mathrm{w}$ \\
Canada & $\mathbf{p}[\mathbf{c}]$ & Mexico & $\ldots$ \\
Chile & $\ldots$ & Netherlands & $\mathrm{w}[\mathrm{c}]$ \\
Czech Republic & $33 \mathrm{w} / 67 \mathrm{p}$ & New Zealand & $\ldots$ \\
Denmark & $\ldots$ & Norway & $\mathrm{w}-0.75$ \\
Estonia & $50 \mathrm{w} / 50 \mathrm{p}$ & Poland & $\mathbf{p}$ \\
Finland & $20 \mathrm{w} / 80 \mathrm{p}$ & Portugal & $\mathrm{p} / \mathrm{GD}$ \\
France & $\mathrm{p} / \mathbf{p}$ & Slovak Republic & $50 \mathrm{w} / 50 \mathrm{p}$ \\
Germany & $\mathrm{w}[\mathrm{c}]$ & Slovenia & $\mathrm{w}$ \\
Greece & $\mathrm{d}$ & Spain & $\mathbf{p}$ \\
Hungary & $\mathbf{p}$ & Sweden & $\mathrm{w}-1.6[\mathrm{c}]$ \\
Iceland & $\mathbf{p}$ & Switzerland & $50 \mathrm{w} / 50 \mathrm{p}$ \\
Ireland & $\ldots$ & Turkey & $\mathbf{p}$ \\
Israel & $\ldots$ & United Kingdom & $\mathbf{p}$ \\
Italy & $\ldots$ & United States & $\mathbf{p}$ \\
Cyprus & $\mathbf{4 0 w / 6 0 p}$ & & \\
\hline
\end{tabular}

Source: OECD, Pensions at a Glance 2011. [c] = indexation conditional on financial sustainability; $d=$ discretionary indexation; $p=$ indexation with prices; $w=$ indexation with average earnings.

\begin{tabular}{|c|c|c|c|c|c|c|c|c|c|}
\hline \multirow[b]{3}{*}{ Australia } & \multicolumn{7}{|c|}{ Pension contribution rate (percent of gross earnings) } & \multirow{2}{*}{\multicolumn{2}{|c|}{$\begin{array}{c}\text { Gross Replacement } \\
\text { Rates 2/ } \\
\text { (in brackets when } \\
\text { replacement rates } \\
\text { for women are } \\
\text { different) }\end{array}$}} \\
\hline & \multirow{6}{*}{$\begin{array}{c}1994 \\
\\
22.8 \\
16.4 \\
5.2\end{array}$} & \multirow{3}{*}{$\begin{array}{l}1999 \\
22.8\end{array}$} & \multirow{2}{*}{2004} & \multirow{2}{*}{2007} & \multirow{2}{*}{$\begin{array}{l}2009 \\
\text { ons onl }\end{array}$} & \multirow{2}{*}{$\begin{array}{c}\text { Employee } \\
2009\end{array}$} & \multirow[t]{2}{*}{$\begin{array}{c}\text { Employer } \\
2009\end{array}$} & & \\
\hline & & & & & & & & & \\
\hline Austria & & & 22.8 & 22.8 & 22.8 & 10.3 & 12.6 & 76.6 & \\
\hline Belgium & & 16.4 & 16.4 & 16.4 & 16.4 & 7.5 & 8.9 & 42.0 & \\
\hline Canada & & 7.0 & 9.9 & 9.9 & 9.9 & 5.0 & 5.0 & 44.4 & \\
\hline Chile & & & 29.8 & 29.8 & 29.8 & 28.8 & 1.0 & $44.9^{\Gamma}$ & (34) \\
\hline Cyprus 1/ & 11.5 & 11.5 & 11.5 & 11.5 & 12.4 & 6.2 & 6.2 & 64.8 & \\
\hline Czech Republic & 26.9 & 26.0 & 28.0 & 32.5 & 28.0 & 6.5 & 21.5 & 50.2 & \\
\hline Denmark & & & Private $\mathrm{p}$ & in cont & ons onl & & & & \\
\hline Estonia & & & 35.0 & 22.0 & 22.0 & 2.0 & 20.0 & 48.0 & \\
\hline Finland & 18.6 & 21.5 & 21.4 & 20.9 & 21.6 & 4.5 & 17.1 & 57.8 & \\
\hline France & 21.5 & 16.7 & 16.7 & 16.7 & 16.7 & 6.8 & 9.9 & 49.1 & \\
\hline Germany & 19.2 & 19.7 & 19.5 & 19.9 & 19.9 & 10.0 & 10.0 & 42.0 & \\
\hline Greece & 20.0 & 20.0 & 20.0 & 20.0 & 20.0 & 6.7 & 13.3 & 95.7 & \\
\hline Hungary & 30.5 & 30.0 & 26.5 & 29.5 & 33.5 & 9.5 & 24.0 & 75.8 & \\
\hline Iceland & & & No sepa & pensio & tributio & & & & \\
\hline Ireland & & & No sepa & ensio & tributio & & & & \\
\hline Israel & & & 6.1 & 6.2 & 6.9 & 3.9 & 3.1 & $69.6^{\prime \prime}$ & $(61.2)$ \\
\hline Italy & 28.3 & 32.7 & 32.7 & 32.7 & 32.7 & 9.2 & 23.8 & $64.5^{\circ}$ & (50.6) \\
\hline Japan & 16.5 & 17.4 & 13.9 & 14.6 & 15.4 & 7.7 & 7.7 & 34.5 & \\
\hline Korea & 6.0 & 9.0 & 9.0 & 9.0 & 9.0 & 4.5 & 4.5 & 42.1 & \\
\hline Luxembourg & 16.0 & 16.0 & 16.0 & 16.0 & 16.0 & 8.0 & 8.0 & 87.4 & \\
\hline Mexico & & & Private $p$ & n cont & ons on & & & & \\
\hline Netherlands & 17.9 & 17.9 & 17.9 & 17.9 & 17.9 & 17.9 & 0 & 88.1 & \\
\hline New Zealand & & & & ontribu & & & & & \\
\hline Norway & & & No sepa & bensio & tributio & & & & \\
\hline Poland & & 19.5 & 19.5 & 19.5 & 19.5 & 9.8 & 9.8 & $59.0^{\circ}$ & $(43.2)$ \\
\hline Portugal & & & No sepa & bensio & tributio & & & & \\
\hline Slovak Republic & 28.5 & 27.5 & 26.0 & 24.0 & 18.0 & 4.0 & 14.0 & 57.5 & \\
\hline Slovenia & & & 24.4 & 24.4 & 24.4 & 15.5 & 8.9 & 62.4 & \\
\hline Spain & 29.3 & 28.3 & 28.3 & 28.3 & 28.3 & 4.7 & 23.6 & 81.2 & \\
\hline Sweden & 19.1 & 15.1 & 18.9 & 18.9 & 18.9 & 7.0 & 11.9 & 53.8 & \\
\hline Switzerland & 9.8 & 9.8 & 9.8 & 9.8 & 9.8 & 4.9 & 4.9 & $57.9^{\prime}$ & (57.1) \\
\hline Turkey & 20.0 & 20.0 & 20.0 & 20.0 & 20.0 & 9.0 & 11.0 & 64.5 & \\
\hline United Kingdom & & & No sepa & bensio & tributio & & & & \\
\hline United States & 12.4 & 12.4 & 12.4 & 12.4 & 12.4 & 6.2 & 6.2 & 39.4 & \\
\hline OECD34 & 19.2 & 19.3 & 20.0 & 19.8 & 19.6 & 8.4 & 11.2 & 57.3 & \\
\hline
\end{tabular}

Sources: OECD (various years), Taxing Wages; OECD (2008), Revenue Statistics; Social Security Administration, United States (various years), Social Security Programs throughout the World; OECD pension and tax models.

1/ A government contribution of 4 percent before 2009 and of 4.3 percent in 2009 is not included for comparability with other countries. The estimated pension contributions are computed deducting an estimated contribution for unemployment insurance close to 1 percent.

2/ Gross replacements rates are computed for workers that earn the average salary during their whole careers and work for

45 years (i.e. a full career worker). 
Appendix Table 5. Age of Mandatory Retirement in Civil Service Pension Schemes

\begin{tabular}{lrlr}
\hline Country & & Country & \\
\hline Denmark & 67 & France & 62 \\
Norway & 67 & Switzerland & 62 \\
Canada & 65 & Austria & 60 \\
Germany & 65 & Belgium & 60 \\
Iceland & 65 & Greece & 60 \\
Japan & 65 & Portugal & 60 \\
Netherlands & 65 & Spain & 60 \\
Sweden & 65 & Australia & $55-601 /$ \\
United Kingdom & 65 & Ireland & $\ldots$ \\
Finland & $63-65$ & Luxembourg & $\ldots$ \\
Cyprus & 63 & & \\
\hline
\end{tabular}

Sources: Civil Service Pension Schemes Around The World, May 2006, Robert Palacios and Edward Whitehouse; Social Protection; the World Bank; and guides to retirement schemes offered to civil servants in the United Kingdom (classic, premium, classic plus, nuvos, partnership scheme guides).

$1 /$ For ordering purposes, mid-point is assumed.

Appendix Table 6. Pension Accrual Rates in Civil Service Pension Schemes 1/

(Percent)

\begin{tabular}{lrlr}
\hline Country & Country & \\
\hline Australia & $1.65-3.4$ & Germany & 1.8 \\
Cyprus 3/ & 2.4 & Greece & 1.7 \\
United Kingdom & 2.3 & Belgium & 1.7 \\
Norway & 2.2 & Luxembourg & 1.7 \\
Netherlands & 2.1 & Finland & 1.5 \\
Austria & 2 & Sweden 2/ \\
Canada & 2 & Italy & $\ldots .33 / 2.17$ \\
France & 2 & Spain & $\ldots$ \\
Portugal & 2 & Switzerland & $\ldots$ \\
Iceland & 1.9 & & $\ldots$ \\
\hline Sources: Civil Service Pension Schemes Around The World, May 2006, Robert Palacios and Edward \\
Whitehouse; Social Protection; the World Bank; and guides to retirement schemes offered to civil \\
servants in the United Kingdom (classic, premium, classic plus, nuvos, partnership scheme guides). \\
1/ For ordering purposes, mid-point is assumed. \\
2/ In Sweden, the pension accrual rate changes depending on revenue level. \\
3/ Takes in to account the lump sum gratuity.
\end{tabular}

Appendix Table 7. Method of Pension Indexation in Civil Servants Pension Schemes

\begin{tabular}{|c|c|c|c|}
\hline $\begin{array}{l}\text { Indexation based on } \\
\text { prices }\end{array}$ & $\begin{array}{c}\text { Indexation based } \\
\text { on civil servant } \\
\text { salaries }\end{array}$ & $\begin{array}{l}\text { Indexation based } \\
\text { on general } \\
\text { salaries }\end{array}$ & Combination \\
\hline $\begin{array}{l}\text { Australia } \\
\text { Switzerland } \\
\text { United Kingdom } \\
\text { Iceland } \\
\text { Spain } \\
\text { Italy } \\
\text { Canada } \\
\text { Netherlands } \\
\text { Sweden } \\
\text { Germany }\end{array}$ & $\begin{array}{l}\text { Austria } \\
\text { Brazil } \\
\text { France } \\
\text { Mexico } \\
\text { Turkey } \\
\text { Cyprus }\end{array}$ & Norway & $\begin{array}{l}\text { Belgium } \\
\text { Denmark } \\
\text { Greece } \\
\text { Luxembourg } \\
\text { Portugal } \\
\text { Finland }\end{array}$ \\
\hline
\end{tabular}

Sources: Civil Service Pension Schemes Around I he World, May 2006, Robert Palacios and Edward Whitehouse; Social Protection; and the World Bank. 


\section{Strengthening Public Financial Management and Managing Fiscal RISKS $^{1}$}

Cyprus is in the process of implementing new fiscal rules and structures, in part in response to EU directives on fiscal governance. As it undertakes these initiatives, it should ensure that they are build on a sound underlying budgetary system with appropriate management of fiscal risks, as discussed in this paper.

\section{A. Background}

1. A sound public financial management system and appropriate management of fiscal risks are important to support the Cypriot government's fiscal consolidation efforts, as well as to improve efficiency, accountability and transparency of public finances. In particular, a budgetary framework that encourages a realistic revenue envelope, prioritizes spending, and sets credible targets is essential. Moreover, fiscal risks that could derail the achievement of fiscal targets need to be identified and minimized. As the authorities undertake reforms of the budgetary system and the framework of public-private partnerships (PPPs), it is useful to draw on advice from IMF technical assistance missions in 2006 and 2007, which identified a number of shortcomings and proposed several reforms:

- $\quad$ On the budgetary system, these included the improvement of revenue and expenditure estimates, the integration of current and development budgets, the removal of excessive budget rigidity and the inclusion of an assessment of fiscal sustainability and fiscal risks in the annual budget documents. In order to better integrate medium-term fiscal implications of government's current policies and increase the alignment of budgetary allocations with government objectives, the gradual introduction of a medium-term budgetary framework (MTBF) and program and performance budgeting (PPB) was recommended.

- $\quad$ Reform proposals on PPPs included strengthening project evaluation and implementation, and enhanced monitoring and oversight capacities by the Ministry of Finance (MoF). In addition, the need to address the absence of a regulatory framework for PPPs was identified.

\section{Significant room for improving the budgetary system and management of}

fiscal risks remains. So far, only initial steps towards the implementation of a broad based budgetary reform have been taken with the integration of current and development budgets and the rolling out of the MTBF/PPB to a number of pilot ministries. On fiscal risks, little progress has been made in reforming the PPP framework and there is weak

\footnotetext{
${ }^{1}$ Prepared by Anke Weber (FAD)
} 
monitoring by the MOF of extra budgetary entities, many of which receive government transfers and guarantees.

3. This paper describes the authorities' reform progress in these areas in more detail, identifies outstanding issues, and discusses reform options. Section II discusses the current status of the budgetary system. It also assesses fiscal risks arising from extrabudgetary activities and PPPs. Section III discusses possible reform options and Section IV concludes.

\section{B. Status of Reforms and Main Outstanding Issues}

\section{The Budgetary Framework}

4. Cyprus has taken some initial steps towards the implementation of broadbased budgetary reform. Both the formulation and evaluation of the current and development budgets are now carried out by the MoF, consistent with international best practice. Previously, separate incremental targets were set for the recurrent and development budgets by the Ministry of Finance and Planning Bureau respectively. Separate budget circulars were issued for which ministries provided estimates. The two agreed budgets were then combined at a later stage of the budget preparation.

\section{The authorities are planning to introduce a medium-term budgetary}

framework together with program and performance budgeting by 2014. The MTBF and PPB, which are to replace an input based annual line item budgeting method, would provide for budgeting by program. Such a framework involves a reorientation of the budget process towards the systematic use of medium-term forecasts of economic and fiscal aggregates to better monitor compliance with government objectives and the medium-term implications of current budget decisions. A new program classification requires all government activities to be classified by a program, which is a group of government activities aimed at achieving a specific outcome. Each program would be accompanied by quantitative and qualitative performance indicators to allow assessment against specific benchmarks.

\section{Initial steps for introducing the MTBF/PPB were taken progressively from}

2007 onwards. Pilot projects were implemented in three line ministries in 2007 that required them to prepare rolling three-year budgets of indicative nature. In 2008, the number of ministries adopting this approach increased. In 2011, all line ministries were required to provide forecasts of their expenditure needs for 2012 and 2013 for the first time and in these forecasts to distinguish between current obligations and future needs. It is expected that by 2013 all ministries will have prepared their financial year budgets according to the traditional input-based budget method and the new PPB/MTBF format in parallel. During this trial period, the accounting software Financial Management Accounting System (FIMAS) will be upgraded to a newer version that is capable of supporting the new budgetary methods and classifications. 
7. Overall progress in implementing the MTBF has been slow due to a variety of difficulties. The MTBF/PPB is only foreseen to become the official budgeting method from the fiscal year 2014 onwards, rather than 2012 as expected until recently. This delay is due to past low government priority in implementing the MTBF and the shortage of skilled personnel to carry out this task as well as technical difficulties encountered with developing the IT system needed to support programme based budgeting.

\section{Several important weaknesses in the budgetary framework remain that could hamper the efficient functioning of the MTBF. These include:}

- $\quad$ Systematic and significant differences between budget estimates and budget execution. Prior to 2008, revenues were typically significantly underestimated, while expenditures were overestimated. Since 2008, revenues and expenditures have been overestimated in the budget. For example, revenues were overestimated by 12,17 and 16 percent, respectively. In the same years, actual expenditure was 2, 6 and 11 percent lower than budgeted. On the revenue side, this was likely due to a misspecification of tax elasticities and asset price growth. On the expenditure side, weaknesses in the preparation of projects and delays in implementation are likely to have been responsible. Another weakness that contributed to deviations is that tax policy measures are usually enacted by separate laws adopted throughout the year resulting in an incorrectly estimated resource envelope at the time of budget approval. This results in a disconnection between revenue and expenditure policies.

- $\quad$ Excessive budget rigidity. The existing budget system does not allow shifting from one line item to another. In combination with projection problems at the budget level this led the government to frequently resort to supplementary budgets during the course of the year to reallocate funds among budget lines and readjust the level of spending.

- Incomplete legal framework for the budget system. The Law on Management of Revenues, Expenditures and the Accounting System does not require presentation to parliament of medium-term macro-fiscal strategies or annual performance plans. There is also no assessment of fiscal sustainability and fiscal risks in the annual budget documents.

\section{Managing Fiscal Risks}

9. International experience has shown the importance of monitoring fiscal risks given their potential to derail fiscal consolidation efforts.

- Public enterprises have often been a significant source of contingent government liabilities, especially as a result of poor management or irresponsible borrowing. Losses or excessive debt have resulted in government bailouts, especially in the aftermath of crises. For example, in 
Thailand bailouts of the non-financial public sector cost the state 15-20 percent of GDP in the early 2000's (Cebotari and others, 2008).

- Public Private Partnerships have resulted in significant contingent liabilities. In Mexico in the 1990s after an ambitious program of private toll road concessions, the concessionaire went bankrupt and the government ended up taking over the private concessions and assuming almost 8 billion USD (2 percent of GDP) in debt. In Hungary in 1995, the government produced overly optimistic traffic forecasts in relation to highway constructions. The PPP contract provided minimum revenue guarantees to the concessionaire, so when traffic was below the original forecasts, compensation from the budget was required (Corbacho and Schwartz, 2008).

\section{Extra-budgetary entities and PPP projects are also important areas that} could lead to fiscal risks in Cyprus. There are a large number of extra budgetary entities and a number of PPPs have been implemented since 1999 and more are planned in the future.

\section{Extra-Budgetary Entities}

\section{There are a large number of semi government entities, most of which are} outside the general government. Semi government is the term given by the authorities to a combination of public corporations and publicly controlled institutions with government functions. In 2010, there were about 33 of these entities. Entities that are inside the general government and therefore part of the public debt figures include the broadcasting corporation, the sports authority, the theatrical organization, the University of Cyprus, and school committees. A number of these entities receive transfers from the budget and can borrow with government guarantees, while others such as the Electricity Authority have their own revenues.

\section{The monitoring of activities of these entities by the Ministry of Finance is}

weak. The Ministry of Finance only approves the budget of each entity, while the monitoring of budget execution is left to the Board of Directors of each entity. The Board of Directors is proposed by the Line Minister and appointed by the Council of Ministers (with the exception of the Sewage Boards). Political parties are represented in the boards of these entities and appointments are not subject to a selection process which screens the candidates in terms of their qualifications. There is an ex post audit of these entities by the Auditor General, with the exception of those public companies under local authorities, which are audited by private auditors. The MoF is given an annual report of these companies. There is no consolidated financial information available to assess the impact of these entities' activities on fiscal policy.

13. Outstanding guarantees to extra-budgetary entities are significant. The total amount is $€ 1.7$ billion at end 2010 (Table 1). These guarantees are reported in the annual 
financial report of the MoF, which is available online. Moreover, liabilities in the form of actuarial deficits and poor practices in the investment of reserves in the pension funds of semi-government entities could require future transfers from the government or increased costs to consumers.

Table 1. Outstanding Guarantees to Public and Other Organizations, 2010

(Millions of euros)

\begin{tabular}{lr}
\hline Organization & Outstanding guarantees \\
\hline Sewerage boards & 589.2 \\
Electricity authority of Cyprus & 458 \\
Central Agency for the Equal Distribution of Burdens & 228.6 \\
Cyprus airways & 46.2 \\
Cyprus ports authority & 43 \\
Other & 300.8
\end{tabular}

Source: Country authorities.

\section{Public-Private Partnerships}

\section{PPPs refer to arrangements in which the private sector supplies} infrastructure assets and services that traditionally have been provided by the government. The majority of PPPs involve some sharing of responsibilities and risks between the public and private sectors. The main argument for PPPs relates to potential efficiency gains with the private sector having superior management capabilities and greater capacity to innovate. This is turn could translate into better quality and lower cost services. However, for this to be the case, it requires efficiency gains large enough to cover the typically higher private sector borrowing costs (Hemming and others, 2006).

15. A number of PPPs have been implemented since 1999. The aggregate contract value of around $€ 1.1$ billion (6.4 percent of GDP). These include airports, marinas and desalination plants (Table 2). A majority of these PPPs are Design-Build-FinanceOperate (DBFO) contracts. Under such a scheme, the government specifies the services it wants the private sector to deliver, and then the private sector designs and builds an asset specifically for that purpose, finances its construction, and subsequently operates the asset (i.e. provides services deriving from it for which it charges fees). In the case of the Larnaca and Paphos airports, some demand Table 2. PPP Projects and Their Estimated Costs (Millions of euros)

\begin{tabular}{lrr}
\hline International airports of Larnaca and Pafos & $200 \tilde{5}$ & 643 \\
Limassol Marina & 2008 & 351.3 \\
Moni desalination plants & 2008 & 9.7 \\
Larnaca desalination plant & 1999 & 41.5 \\
Dekelia desalination plant & 2005 & 13.2 \\
Paphos desalination plant & 2009 & 18.1 \\
Lemesos desalination plant & 2009 & 45.8 \\
Garillis water treatment plant & 2008 & 1.9 \\
Larnaka Port and Marina re-development & expected 2012 & Infrastructure \\
project & & investment: 115 \\
& & (Phase 1 only); land \\
Total & & development 400 \\
Total (excluding planned project) & & 1639.5 \\
\hline
\end{tabular}

Source: Country authorities. the operator to postpone the 
payment of variable revenues if passenger levels fall below a certain threshold. This already happened in 2009 , when revenues amounting to $€ 14.4 \mathrm{~m}$ were retained by the operator and were received by the government during 2010, at the end of the shock event period. Another large PPP project, the Larnaka Port and Marina Redevelopment project, is planned for 2012 .

\section{The framework under which these PPPs were implemented suffers from} several weaknesses which are not conducive to maximize efficiency gains and could expose the budget to fiscal risks. These include:

- $\quad$ Poor project evaluation. There is little use of economic analysis tools such as value for money (VfM) and cost benefit analysis (CBA) and minimal project documentation requirements. There is also no regular evaluation of investment projects and ex-post analyses or auditing of investment projects.

- The absence of an effective "gateway process". A gateway is an institutional device that allows the Ministry of Finance to stop or suspend a PPP project that does not offer VfM or is fiscally not affordable. The MoF is not well informed of PPPs undertaken by line ministries. This is because of a decentralized government structure where line ministries are essentially in charge of PPPs in their own sector. There is also no dedicated PPP unit in the MoF or in the Planning Bureau to monitor PPPs. This opens the door to the implementation of PPPs that involve substantial government implicit or explicit guarantees and whose risks and fiscal implications have not been appropriately captured in government financial statements or disclosed in budget documents.

- $\quad$ The absence of a regulatory framework for PPPs. While a tender process concerning the provision of services for the study and regulation of PPPs was launched in 2007-08, it was stopped due to legal proceedings over its legality and no further progress has been made since then.

\section{Reform Options}

\section{The Budgeting Framework}

17. The weaknesses of the budgetary framework in Cyprus are particularly concerning at a time when public finances are under stress. This has been highlighted by the experience of other European economies, where weak and fragmented PFM systems have contributed to significant expenditure overruns and arrears and impeded the government's ability to set credible targets backed by high quality measures.

\section{The following is recommended in order to facilitate a well functioning medium-term budgetary framework:}


- $\quad$ Enhanced methods of revenue forecasting should be developed. Revenue forecasting, particularly in relation to taxes sensitive to asset price changes, should be strengthened. Moreover, a realistic resource envelope for budget decisions should be ensured, by incorporating any planned tax policy measures at the time of budget approval.

- $\quad$ The currently excessively detailed budget classification should be collapsed into a number of broader economic groupings to allow increased flexibility to reallocate spending. Implementing an international standards budget classification such as the IMF GFS 2001 could help achieve this objective.

- $\quad$ The legal framework should be enhanced. In particular, changes necessary to ensure that a budget classified by programs is adopted by parliament should be implemented in order to facilitate the swift introduction of PPB. In the mediumterm, the Law on Management of Revenues, Expenditure and the Accounting System should be transformed to a comprehensive public finance law. The new law should provide for the presentation to parliament of medium-term macro fiscal and budget strategies, objectives and annual performance plans, and an assessment of fiscal sustainability and fiscal risks - including the longer-term sustainability of the social insurance fund, and risks associated with loans, loan guarantees, and PPPs, strategies and management plans for government debt and other significant liabilities. Consideration could also be given to require the presentation to parliament of a midyear economic and fiscal outlook report to improve the information parliament receives to assess budget developments.

\section{Managing Fiscal Risks}

\section{The proposals discussed below could help improve managing fiscal risks in} the areas of extra-budgetary entities and PPPs. These proposals seek to strengthen the oversight capacity of the Ministry of Finance and increase the availability of information on fiscal risks:

\section{Extra-Budgetary Activities}

- In the short term, it is important to ensure that the activities of large extra budgetary entities are monitored and scrutinized by the Ministry of Finance. The focus on the largest entities is justified given their potential to create the largest fiscal risks. There are several options on how to design the exact institutional framework. One possibility would be for the MoF to collect all public enterprise data on a consolidated basis and closely monitor entities in financial difficulties, as is the case in Hungary and Italy (IMF, 2007). A special unit could also be set up at the Ministry of Finance to supervise the financial operations of extra budgetary entities (Indonesia and Montenegro). In addition to approval of public enterprise budgets, approval of investment and borrowing and stepped up 
monitoring of public enterprise operations could also be required by the MoF (Chile, Columbia and Peru).

- $\quad$ Timely and comprehensive reporting of financial operations to the Ministry of Finance should be ensured to facilitate effective monitoring. The Ministry of Finance should require submission of audited financial statements covering at least revenue, expenses, investment expenditure, overall balance, sources of financing and debt. The Ministry of Finance should also receive on a regular and timely basis other information that it needs to carry out effective oversight, such as costs, employment, pricing and investment policies, as well as comprehensive information on the pension systems of semi-government entities.

- A consolidated report that shows the overall fiscal implication of these entities should be produced and published by the Ministry of Finance. GFSM 2001 consolidated financial accounts could be constructed on the basis of the financial statements of the extra-budgetary entities with appropriate bridge tables. This would also facilitate the production of statistics on extra-budgetary entities that is consistent with the System of National Accounts.

- In the medium-term, consideration should be given to rationalize the number of extra budgetary entities. This can be achieved by liquidating entities which are no longer needed, and bringing back into the budget entities which carry out government functions but lack adequate rationale for operating as autonomous entities. Privatization programs could also be considered for suitable organizations.

\section{Public-Private Partnerships}

- $\quad$ Ex-ante analysis of the economic rationale for different projects and regular evaluation of different projects is needed to enhance public investment planning. This will involve both cost benefit analysis and value for money assessments when deciding on whether to go ahead with a PPP. The oversight responsibilities of the Planning Bureau for ongoing and completed public investment projects should be also strengthened. This would be facilitated by setting up a central PPP unit in the Planning Bureau staffed with a team of multidisciplinary experts. This unit should have responsibilities in three main areas: VfM assessments, providing advisory services and supplying oversight. Ex-post analyses and audits should be conducted at a minimum on the largest projects.

- An effective "gateway process" that strengthens the role of the Finance Minister and budget directorate of the Ministry of Finance should be established. This would need to be installed at specific stages of negotiating a PPP project. The gateway process ensures that key project steps and decisions are systematically communicated to the $\mathrm{MoF}$, which can then stop or request modifications for a project that is deemed too risky for budgetary purposes. 
- $\quad$ Fiscal management laws to strengthen role of MoF in reviewing and approving PPPs should be adopted. For example, the Law for the Management of Revenues and Expenditure and of the Accounting System should be amended to state that all fiscal implications of PPPs are properly considered by decision makers as part of the budget process before the decision to go forward with a project is taken. This would ensure that large government investment projects do not fall outside the normal procedures for spending prioritization. A framework law for PPPs should also be developed and a clear statement on the government's PPP strategy should be issued with accompanying guidelines that establish key functions and broad parameters of project selection and risk allocation.

\section{Conclusion}

20. Laying the foundation on which a well functioning medium-term budgetary framework can be implemented should be given the highest priority. A realistic time bound action plan should be developed that takes into account the current situation, outlines a step by step approach on how to strengthen areas of identified weaknesses, and then builds on these reforms to fully implement a medium term budgetary framework.

\section{References}

Cebotari, A., J. Davis, L. Lusinyan, A. Mati, P. Mauro, M. Petrie, and R. Velloso, 2008, "Fiscal Risks: Sources, Disclosure, and Management," Departmental Paper 09/01, Fiscal Affairs Department (Washington: International Monetary Fund).

Corbacho, A., and G. Schwartz, 2008, "PPPs and Fiscal Risks: Should Governments Worry?" in Public Investment and Public-Private Partnerships, ed. By G.

Schwarz, a. Corbach, and K. Funke (Washington: International Monetary Fund).

Hemming, R., M. Alier, B. Anderson, M. Cangiano, and M. Petrie, 2006, "Public-Private Partnerships, Government Guarantees, and Fiscal Risk," (Washington: International Monetary Fund).

International Monetary Fund (IMF), 2007, Public Enterprises and Fiscal Risk—Lessons from the Pilot II Country Studies (Washington: International Monetary Fund). 


\section{EXTERNAL COMPETITIVENESS ${ }^{1}$}

Cyprus' service exports driven growth model is facing challenges in terms of weakened external demand and increasing competition from other countries in the region. The question of external competitiveness boils down to whether Cyprus has the potential to continue growing at current real exchange rates. This question has now gained importance and urgency as the economy is facing numerous shocks that are likely to hamper domestic demand for an extended period. To put the economy back on a growth path, policies to reduce wage rigidities and enhance productivity are vital to boost export performance and growth.

\section{A. Introduction}

1. Persistent current account deficits expose Cyprus to increasing vulnerabilities as recent distress in financial markets makes foreign financing more uncertain. The current account deficit, which had been averaging 3 percent of GDP up until 2004, has been steadily widening since accession to the EU and currently stands at over 7 percent of GDP. While its financing has not been a problem in the past, given large inflows of FDI and non-resident deposits, the availability of these resources is not guaranteed going forward, as repeated downgrades of the sovereign and deteriorating macro risks have seriously diminished Cyprus' attractiveness for foreign investment, at the same time as continued slowdown in the rest of Europe exacerbates the decline in foreign demand and FDI inflows. Non-financial corporations are highly indebted to banks and make the private sector highly vulnerable to banks' lending capacity and interest rate changes.

2. While growth in service exports has been partially compensating for the negative merchandize trade balance, their continued dynamism is not guaranteed. In the context of rapid unit labor cost growth and the associated real exchange rate appreciation, Cyprus' goods have been increasingly priced out of international markets since the early 1990s, contributing to a goods trade deficit of 20-30 percent of GDP in the last decade. Services exports, in particular business services, shipping and financial intermediation have been partially offsetting this trend. However, continued dynamism of these sectors needs to be supported by measures to strengthen Cyprus' price competitiveness and reforms to enhance productivity.

3. This note reviews the development of Cyprus' services sector and its contribution to external trade, analyzes empirically the role of relative prices for service export growth, and examines other factors that determine Cyprus' capacity to compete in the world markets. The note is structured as follows. Section B puts Cyprus labor market indicators into regional perspective. Section $\mathrm{C}$ lays out recent trends in exports, focusing in

\footnotetext{
${ }^{1}$ Prepared by Mai Chi Dao (EUR)
} 
particular on the role of service exports. Section D provides an empirical analysis of the role of relative prices for service export dynamics. Section E discusses other aspects of competiveness and section F concludes.

\section{B. Labor Market Indicators}

4. Cyprus has a history of very low unemployment rates and short unemployment durations, in contrast to many other peripheral Euro area countries. Unemployment averaged around 4 percent from 2000 to 2008. In fact, the economy was faced with labor shortage and relied heavily on immigrant inflows to cover the shortage, particularly in low skill sectors. Within the EU, the net migration rate of 11 percent over the period from 2000 to 2009 was only second to Spain. The labor market also did not show signs of significant structural unemployment, as is reflected in the lowest rate of long-term unemployment in the Euro area. However, the crisis has not left Cyprus' labor market unscathed: its unemployment currently stands at 7.6 percent, still below the Euro average of 9.9 percent but historically at the highest level for Cyprus.

\section{Cyprus has a low tax wedge on labor, low replacement rate, and duration of} unemployment benefits, and hence does not suffer from financial disincentives to labor participation. Cyprus' average tax wedge on labor, at 14 percent for the average single wage earner, is by far the lowest within the EU². Likewise, Cyprus' unemployment benefits are among the least generous in the EU. Although the initial net replacement rate of 58 percent lies in the range of other EU countries, the benefit duration of only 5 months is extremely short. Unlike in many countries, where lower but more long-term unemployment assistance is often available after the expiration of the unemployment insurance payment, such a scheme does not exist in Cyprus.

6. Cyprus has a very high share of employment in service sectors and a large public sector. The high service content of production, employment and exports is one major characteristic that sets Cyprus apart from the rest of the region. The most dynamic service sector is financial intermediation, whose value-added already exceeds that of tourism. Although a transition from agriculture/manufacturing to services is typical for countries during the process of convergence and modernization, Cyprus' service intensity still stands out when compared with either a large mature economy like the UK, or small open economies like Malta or Luxembourg, which all have large banking systems as well. Another salient feature of the Cypriot economy is the large share of the public sector. Spending on wages by the general government makes up almost 15 percent of GDP, the highest level in the EU. One important implication of such a dominant public sector is that wages set for government employees act to a large degree as an anchor for wage developments in the

\footnotetext{
${ }^{2}$ Data is as of 2007, taken from Labour Market Developments in Europe, 2011.
} 
private sector. This has been one reason why wages in Cyprus have often not been in line with productivity dynamics.

\section{Real wages rose during the downturn in 2009 at one of the highest rate in the} Euro area and do not co-move with cycles in economic activity. As the crisis hit in 2009, Cyprus experienced its first downturn in more than 30 years. Yet, average real wages increased by 3.6 percent, one of the highest growth rates in Europe. ${ }^{3}$ The fact that a major negative shock to growth and employment did not trigger a downward adjustment in wages points towards a lack of flexibility to cushion the contraction. But also looking at the correlation of wage and GDP growth during an extended period before the crisis, Cyprus shows a large negative correlation, meaning that changes in wage growth in general do not move in tandem with changes in the business cycle.

\footnotetext{
${ }^{3}$ Although in Ireland, real wages rose by more than 4 percent, almost all of that increase was driven by the deflation that Ireland suffered during the downturn, while nominal wages hardly budged,
} 
Figure 1. Cyprus Labor Market in Regional Perspective

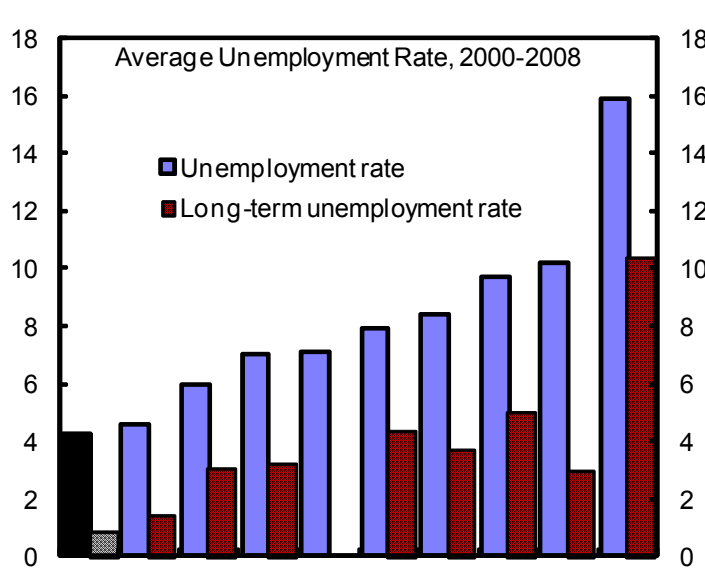

CYP IRL SVN MLT PRT ITA EU27GRC ESP SVK
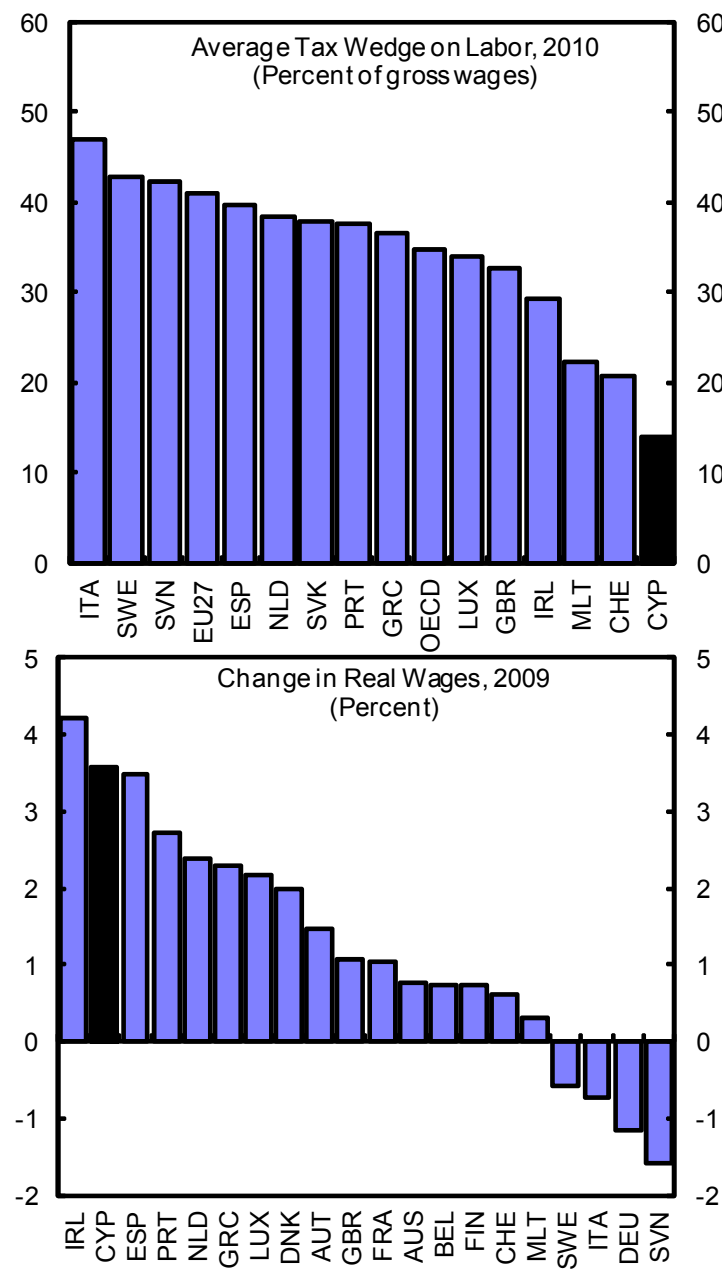
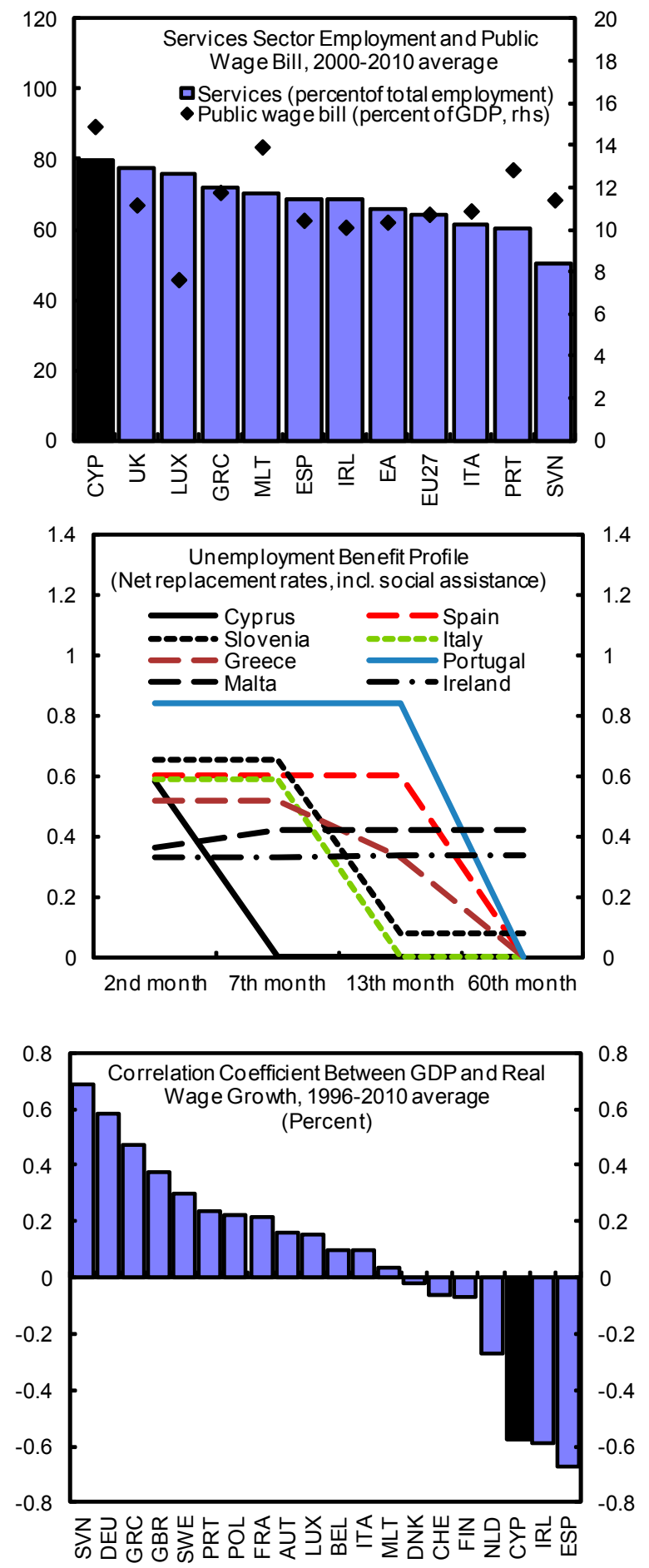

Sources: Eurostat; OECD Taxing Wage; European Commission; AMECO; and European Commission, Labor Market Developments in Europe, 2011. 


\section{The Evolution of Service Exports}

8. Cyprus is a small open economy specializing in exports of services and relying on imports of goods and commodities. With a trade share of over 50 percent of GDP, the trade balance contributes substantially to variation in GDP growth. In the years leading up to the crisis, the trade balance was mainly driven by deficits in the goods balance (fuel, equipment, vehicles), which was only partially offset by positive net exports in services (tourism and business services).

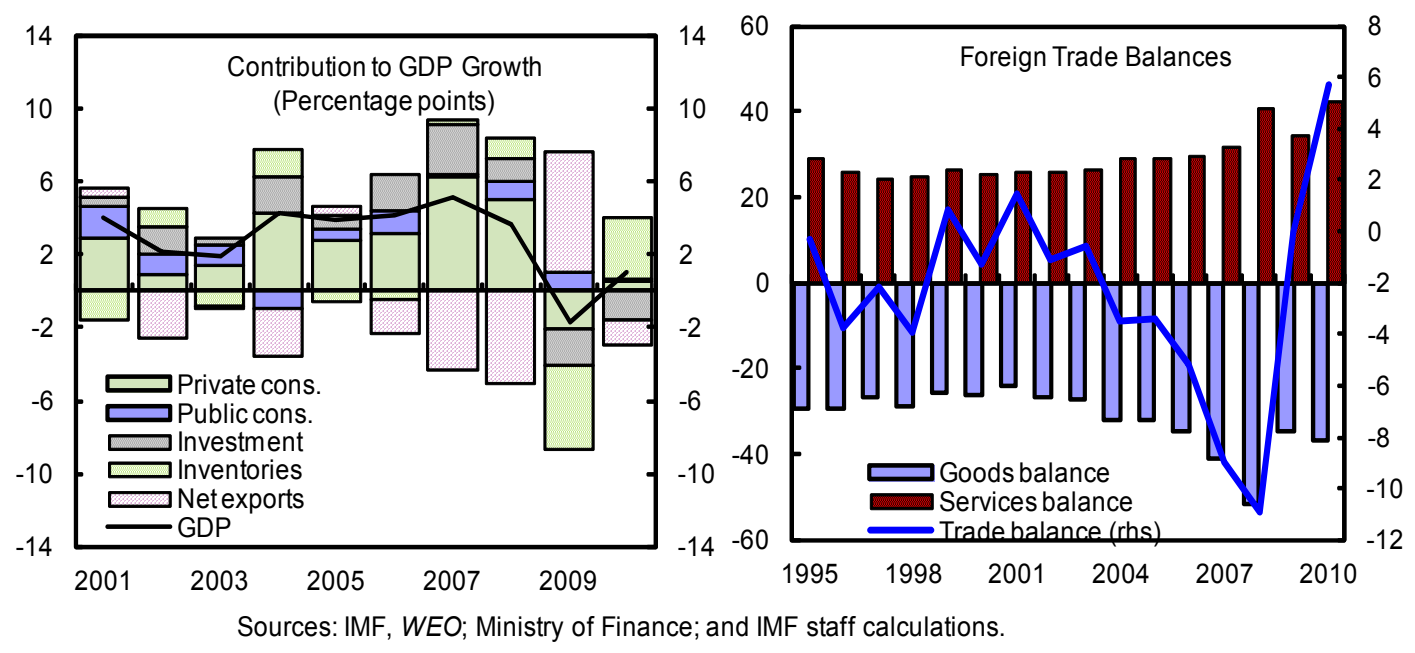

9. The goods trade balance has been persistently negative at over 20 percent of GDP since the mid 1990s, reflecting the steady erosion of market shares. While many countries in Southern Europe have been facing losses in export market shares due to deteriorating competitiveness upon joining the EU, the pace of loss for Cyprus has been among the fastest. At the same time, market share of service exports has been largely constant, with a spike in 2008-2009, when Cyprus service exports contracted less than elsewhere in the world.
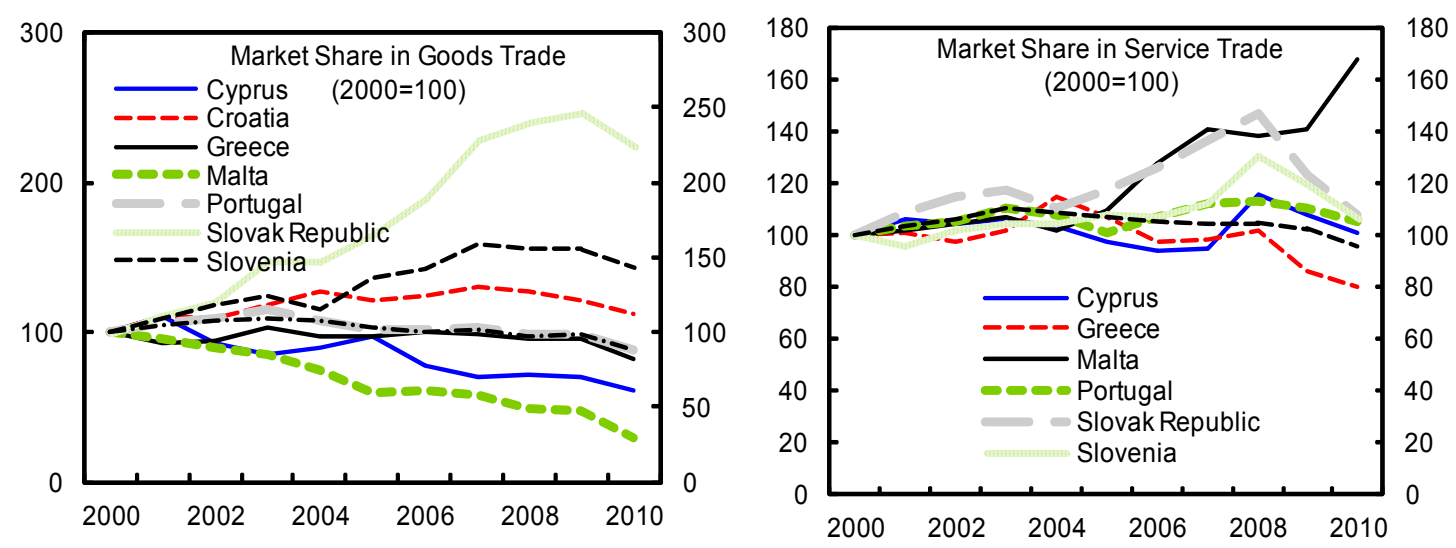

Sources: IMF, Direction of Trade Statistics; Eurostat; and IMF, WEO. 
10. Service exports are increasingly driven by business and financial services, while the contribution of tourism has been declining. Traditionally, tourism has been the main export sector due to Cyprus' favorable geographic location and climate. Over the last decade however, its share in total GDP has halved from 20 to less than 10 percent, while that of exports of business services and financial intermediation has increased from 10 to almost 29 percent of GDP. The expansion builds on Cyprus' low corporate tax rates and double-tax treaties, which attracted international offshore companies, creating demand for local legal and accounting services. Additionally, demand for vacation homes by foreigners has led to a boom in real estate related services in the run-up to the crisis.

\section{While the UK and Germany have been traditionally the main destinations for} Cypriot service exports, Russia has rapidly gained importance in recent years. Exports volatility has been strongly influenced by demand conditions in Europe and the US, Cyprus' main trading partners. The large drop in tourism in 2009 was driven by external demand slowdown, particularly in the UK, which accounts for about half of total tourism. However, the increasing presence of Russian travelers, real estate investors, and offshore companies, and the relative buoyancy of Russian demand compared to that in the EU have provided some positive impulse in 2011, leading to a substantial recovery in tourism. In 2009, Russia overtook the UK as the largest export market for Cypriot services. In June to August 2011, tourism revenues from Russia rose 52 percent (year-on-year) compared to a 16 percent increase overall.

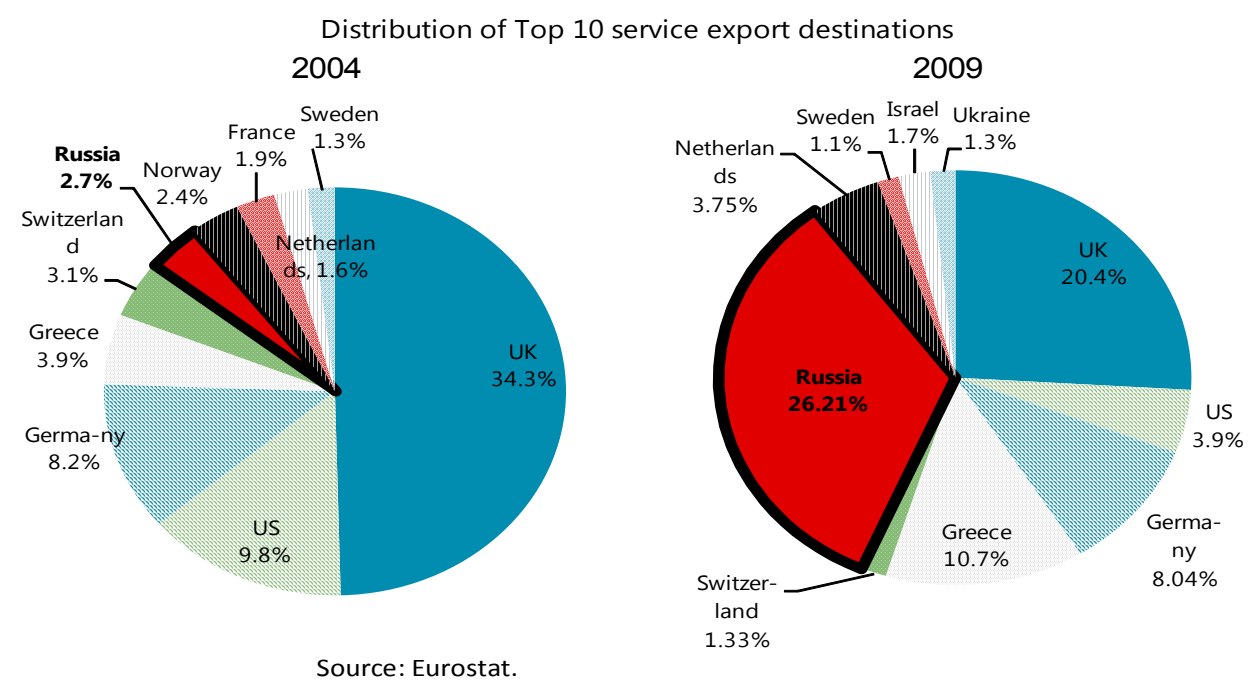


12. The drop in Cyprus' exports at the peak of the crisis in 2009 was mild compared to other Euro zone countries, as was its recovery in 2010, likely due to lower reliance on manufacturing exports. Although tourism activity did decline substantially, exports of other services (transport, financial and business) held up relatively well during the downturn in 2009. At the same time, exports across all sectors staged only a weak recovery in 2010 . This largely mirrors the fact that countries which have a relatively high service share in total exports tend to be less sensitive to swings in external demand. While the subdued cyclicality of service exports might have protected Cyprus against the slowdown in external demand, it also poses limits to an export-led recovery once external conditions improve.
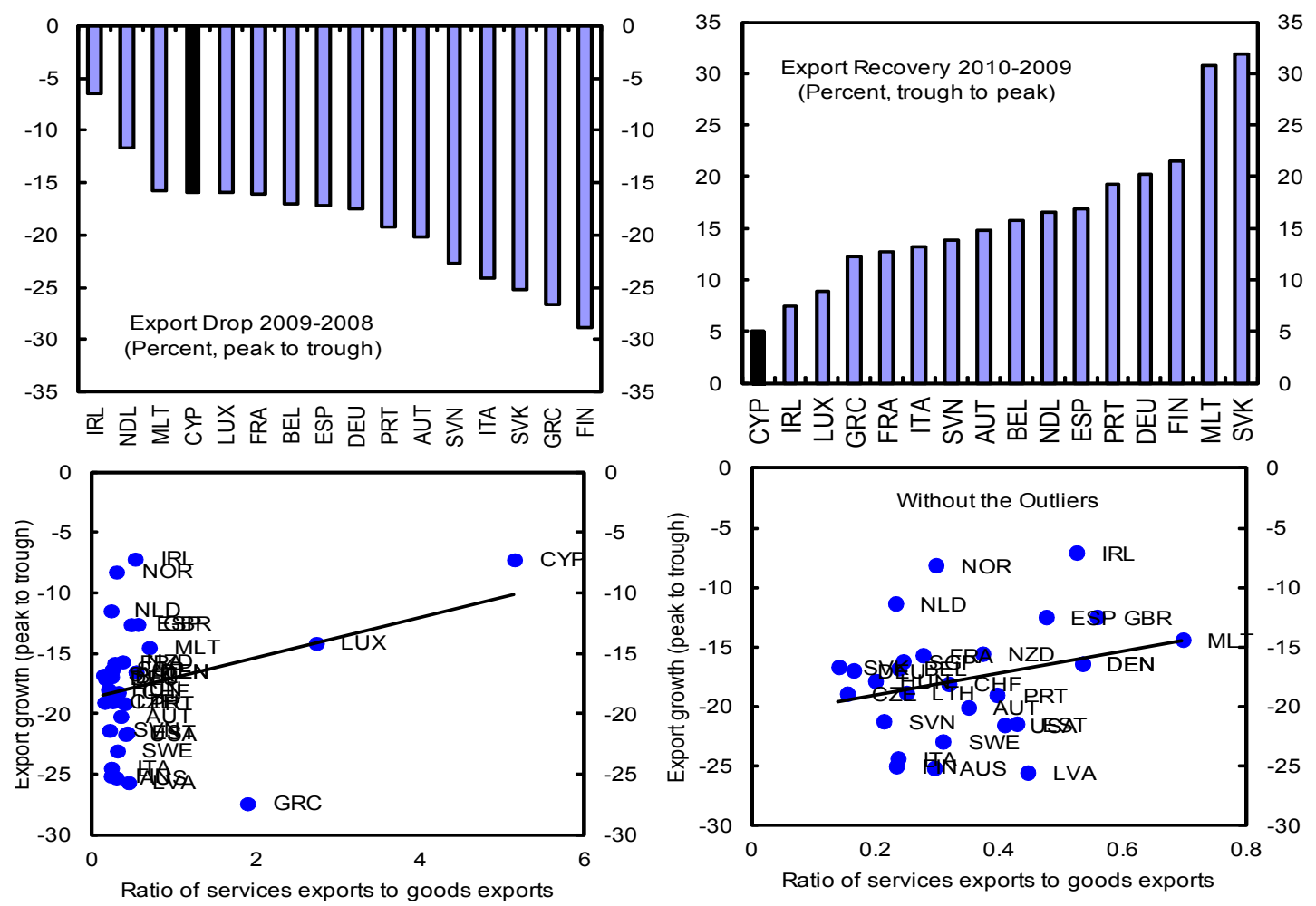

Sources: Eurostat; and IMF staff calculations.

\section{The Role of Relative Prices}

\section{The real exchange rate has been} appreciating since 2000 in line with other peripheral Euro zone countries. The unit labor cost (ULC) based real effective exchange rate appreciated rapidly ahead of the EU accession, mainly driven by fast growth in labor costs as the CPI-based real exchange rate measure appears more stable. Unlike in other Euro area countries, there was hardly any real depreciation in the ULC-based measure in

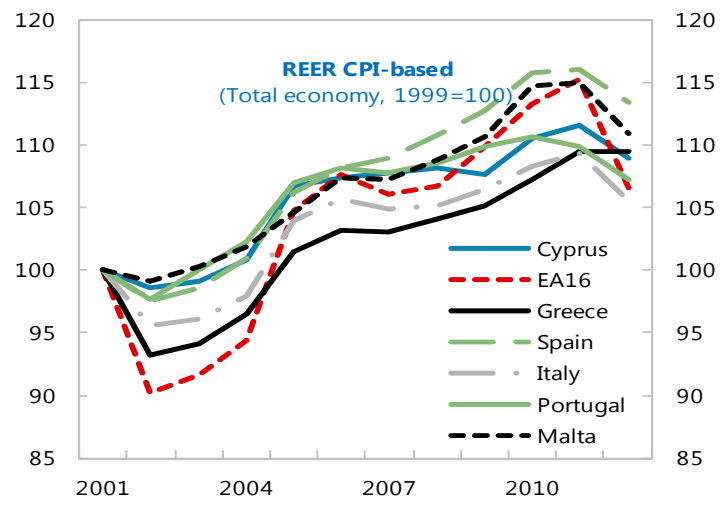


response to the downturn in 2010. The apparent lack of downward flexibility of the exchange rate is likely caused by wage rigidities imposed by the cost of living adjustment (COLA), which indexes wages to past inflation. Downward wage and price flexibility is particularly important given lack of nominal exchange rate flexibility within the monetary union.

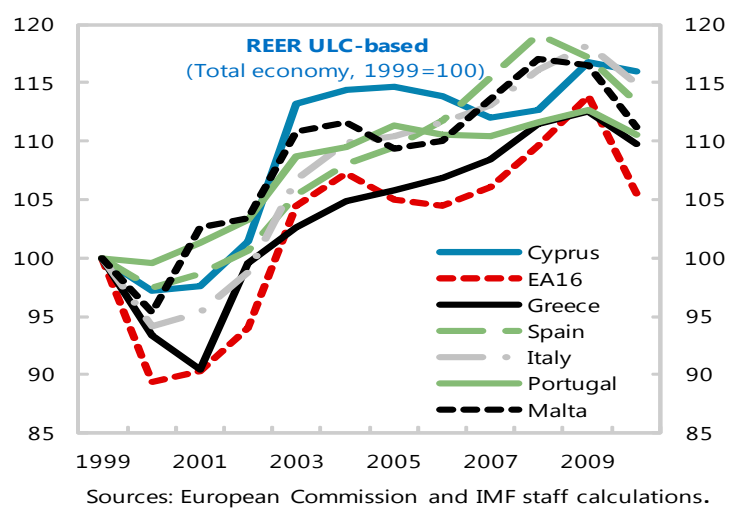

\section{A cross-country regression exercise suggests that exports of services are less} sensitive to external demand, but respond similarly to real exchange rate movements as goods exports. Being a service economy, one might expect Cyprus to respond differently to fluctuation in world trade activity than countries specializing in goods and commodity exports. One might also think that service exports are less substitutable and hence less sensitive to exchange rate movements than goods exports. To approach this question, a crosscountry panel regression was used to estimate an export demand equation for goods and services separately and statistically test for differences in their behavior. The sample includes both EU and non-EU European countries, as well as the US, Australia and New Zealand, covering the period from 1994 to 2010. In the baseline specification, export volume is assumed to depend on external demand, measured by a weighted average of trading partners' income $\left(\mathrm{Y}^{*}\right)$, the real effective exchange rate, CPI-based (REER) and ULC-based (ULCRE), structural break due to the Euro (EUR) adoption, and unobservable country and year fixed effects $\left(\mu_{\mathrm{i}} \text { and } \mu_{\mathrm{t}}\right)^{4}$ :

$$
\exp _{i t}=\alpha+\beta_{1} Y_{i t}^{*}+\beta_{2} R E E R_{i t}+\beta_{3} E U R+\mu_{i}+\mu_{t}+\varepsilon_{i t}
$$

The estimation results are summarized in Table 1. Two main findings stand out:

- Goods exports are highly dependent on external demand, but services exports less so: A 1 percent increase in trading partner growth is associated with a 2 percent increase in real export growth for goods. The demand elasticity for services has less than half the magnitude and is not statistically significant.

- $\quad$ Both goods and service exports respond significantly to real exchange rate movements, measured either by the CPI-based or the unit labor cost-based real effective exchange rate. Moreover, the magnitude of the exchange rate elasticity is similar for goods and services: a 1 percent real appreciation leads to a 0.16 to 0.26 decrease in export growth, depending on the specification. In fact, a formal Wald test

\footnotetext{
${ }^{4}$ See the appendix for variable definition, sources and sample coverage.
} 
cannot reject the hypothesis that the exchange rate elasticity is equal for both goods and service exports.

Table 1. Regression Results $1 /$

\begin{tabular}{lrrrr}
\hline & \multicolumn{5}{c}{ All countries } \\
\cline { 2 - 5 } & \multicolumn{5}{c}{ Goods exports } & \multicolumn{3}{c}{ Services exports } \\
\cline { 2 - 5 } External demand & $2.087^{* * *}$ & $2.190^{* * *}$ & 0.665 & $0.976^{*}$ \\
REER & $(0.430)$ & $(0.448)$ & $(0.496)$ & $(0.518)$ \\
& $-0.255^{* * *}$ & $\ldots$ & $-0.194^{* * *}$ & $\ldots$ \\
ULCRE & $(0.061)$ & $\ldots$ & $(0.070)$ & $\ldots$ \\
R2 & $\ldots$ & $-0.213^{* * *}$ & $\ldots$ & $-0.156^{* * *}$ \\
N & $\ldots$ & $(0.050)$ & $\ldots$ & $(0.057)$ \\
& 0.514 & 0.532 & 0.323 & 0.342 \\
Countries & 542 & 503 & 542 & 503 \\
\hline
\end{tabular}

Sources: Eurostat; European Commission; and IFS.

1/ All regressions include a full set of country and time fixed effects and a Euro dummy for countries and years with Euro adoption; robust standard errors are in parantheses; ${ }^{* * *},{ }^{* *}$, * denote statistical significance at the 1,5 , and 10 percent level respectively.

For Cyprus, this finding is consistent with analyses of the tourism sector which report that its main weakness is the deteriorating price competitiveness reflected in high prices for transport, accommodation and general living costs (see WEF, 2011a).

\section{The euro adoption is associated with a stronger sensitivity of goods exports to real exchange rate movements.}

The sample includes euro and noneuro area countries, and for the former, years prior to joining the currency union. Therefore, it is possible to test whether the adoption of the common currency made member countries' exports more or less sensitive to relative price Table 2: Regression Results with Interaction Terms 1/ fluctuations, compared to the control group of non-euro countries and/or years. We estimate the euro effect by interacting each measure of the real exchange rate with a dummy variable that, for each country,

\begin{tabular}{|c|c|c|c|c|}
\hline \multirow[b]{3}{*}{ External demand } & \multicolumn{4}{|c|}{ All countries } \\
\hline & \multicolumn{2}{|c|}{ Goods exports } & \multicolumn{2}{|c|}{ Services exports } \\
\hline & $\begin{array}{r}2.217^{* * *} \\
(0.356)\end{array}$ & $\begin{array}{r}2.269^{* * *} \\
(0.346)\end{array}$ & $\begin{array}{r}0.811 \\
(0.516)\end{array}$ & $\begin{array}{r}0.815 \\
(0.526)\end{array}$ \\
\hline REER & $\begin{array}{r}-0.256^{* * *} \\
(0.050)\end{array}$ & $\begin{array}{l}\ldots \\
\ldots\end{array}$ & $\begin{array}{r}-0.184^{\star *} \\
(0.073)\end{array}$ & $\begin{array}{l}\cdots \\
\cdots\end{array}$ \\
\hline REER xEUR & $\begin{array}{l}-0.305^{*} \\
(0.184)\end{array}$ & $\ldots$ & $\begin{array}{r}0.003 \\
(0.267)\end{array}$ & $\ldots$ \\
\hline ULCRE & $\begin{array}{l}\ldots \\
\ldots\end{array}$ & $\begin{array}{r}-0.204^{\star \star *} \\
(0.039)\end{array}$ & $\begin{array}{l}\ldots \\
\ldots\end{array}$ & $\begin{array}{r}-0.141^{* *} \\
(0.060)\end{array}$ \\
\hline ULCRE xEUR & $\begin{array}{l}\ldots \\
\ldots\end{array}$ & $\begin{array}{r}-0.501^{* * *} \\
(0.162)\end{array}$ & $\begin{array}{l}\ldots \\
\ldots\end{array}$ & $\begin{array}{l}-0.188 \\
(0.246)\end{array}$ \\
\hline R2 & 0.637 & 0.671 & 0.332 & 0.343 \\
\hline $\mathrm{N}$ & 520 & 491 & 520 & 491 \\
\hline Countries & 36 & 36 & 36 & 36 \\
\hline
\end{tabular}

Sources: Eurostat; European Commission; and IFS.

1/ All regressions include a full set of country and time fixed effects and a Euro dummy for countries and years with Euro adoption; robust standard errors are in parantheses; ${ }^{* * *},{ }^{* *},{ }^{*}$ denote statistical significance at the 1,5 , and 10 percent level respectively. equals one from the year it adopts the euro. This additional term, measuring the euro "treatment" effect is added to the baseline regression equation. The results are summarized in Table 2 for the whole sample. 
- $\quad$ The estimates for the euro treatment effect are significant and negative for exports of goods. That is, upon joining the euro area, a country's goods exports become more sensitive to real exchange rate changes - a real appreciation of 1 percent now has a negative effect of -0.5 to -0.7 percent on exports growth (more than double the average effect of -0.2 to -0.25 ). This finding has been reported in other recent studies (e.g. Bayoumi et al., 2011). A possible reason for this increased sensitivity to exchange rate movements could be financial and product market liberalizations that occurred with the euro adoption. Liberalization removed many non-price barriers to trade and gave relative prices a stronger signal of competitiveness. Moreover, as the euro adoption was preceded by a period of reduced exchange rate volatility for countries in the ERM, uncertainty about the future path of the exchange rate, and hence about the permanence of changes in competitiveness was lowered. This as well could enhance the signaling effect of relative prices.

Joining the euro area does not seem to change the sensitivity of service exports to exchange rate movements. Relative to product markets, services markets are more regulated at the national level, hence subject to more non-trade barriers even after Euro adoption.

\section{E. Other Aspects of Competitiveness}

\section{Administrative inefficiencies and severe regulations still pose obstacles to the}

business environment. Cyprus currently ranks $40^{\text {th }}$ among 183 countries worldwide in terms of the Ease of Doing Business as measured by the World Bank (World Bank, 2012), and $47^{\text {th }}$ among 142 countries in terms of broader competitiveness as measured by the World Economic Forum (WEF, 2011b). Notwithstanding recent reforms to improve the regulatory environment, which include the set-up of one-stop shop for new business registration and strengthened investor protection through greater corporate disclosure, serious impediments remain. Compared with other advanced countries, Cyprus ranks only $39^{\text {th }}$ out of 48 for its ease of enforcing contracts, due to numerous procedures and long waiting times to resolve disputes in courts. The private sector also complains about severe restrictions in key transport sectors in terms of working hours (e.g., ports, warehouses) and access to license to operate (e.g., trucks).

\section{While envisaging further transition to high} value-added services, Cyprus still lags in terms of technological innovation and adoption. In spite of the high quality of the education system, Cyprus ranks weakly in terms of its capacity for innovation and $\mathrm{R} \& \mathrm{D}$, a critical dimension for competitiveness defined

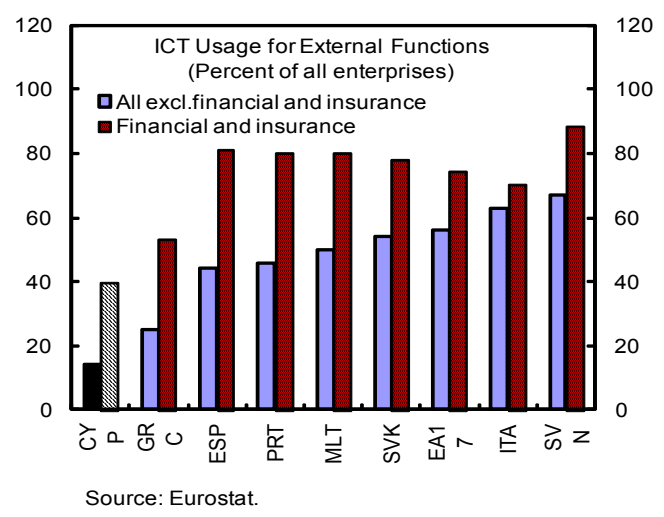


by the Lisbon Strategy. ${ }^{5}$ Aggregate spending on R\&D, at 0.4 percent of GDP, is the lowest in the EU and far below the EU target of 3 percent of GDP. As for adoption of existing technology, the share of enterprises using information and communication technologies (ICT) for external business functions (e.g., supply, financial, client management) is the lowest in the euro zone.

\section{F. Conclusion}

\section{Cyprus competitiveness derives from its service exports, which have enjoyed} strong growth thanks in large part to a favorable tax regime and an educated English speaking workforce. Along the steady transition towards a service economy, there has been a gradual shift to business and financial services away from traditional manufacturing and tourism. At the same time, new markets (predominantly Russia) have provided additional impulse for export expansion in recent years. Prior to the crisis, this growth model contributed to strong labor market performance, but was accompanied by a rapid expansion of the public sector and fast increase in labor cost.

\section{Going forward, efforts to reduce wage rigidities are central to preserve} competitiveness, in particular in the absence of nominal exchange rate flexibility. Although reliance on the business friendly tax regime has proved successful in the past, its potential for further benefit is limited given increasing tax competition from other countries, as well as limits posed by government finances and EU-wide regulations. Going beyond the tax regime, relative prices are an important determinant of service exports, as shown by empirical evidence. Absent control over nominal exchange rates and commodity prices, wages need to be sufficiently flexible to adjust to shocks such as the recent crisis and facilitate reallocation of factors across sectors. The most effective way to reduce wage rigidities is to reform or eliminate the COLA. This would also direct more skilled workers into the private sector as the COLA contributes to high public sector wages.

\section{To ensure ongoing dynamism as Cyprus continues its transition to high value-} added services, there is need for improved business climate and technological sophistication. The authorities should identify regulatory hurdles affecting contract enforcement and the efficient functioning of transport services discussed above and lay out appropriate reforms. They should explore what obstacles hinder more widespread technology adoption by businesses. Initial measures to support Cypriot firms in their efforts to upgrade technology and enhance productivity have been included in the National Reform Program.

\footnotetext{
${ }^{5}$ According to the Lisbon Review 2010, Cyprus ranks $13^{\text {th }}$ out of 27 EU countries in terms of overall competitiveness, but only 21 th in terms of the sub-category Innovation and R\&D.
} 


\section{Annex}

\section{Data sample underlying estimations in Table 1 and 2:}

- Countries: all current EU-27 countries, plus Croatia, Iceland, Norway, Switzerland, Unites States, Canada, Australia, New Zealand, Turkey.

- Years: $1994-2010$.

- Variables and sources:

○ exp: exports of goods/services in constant prices, from WEO, IFS (IMF) and Eurostat.

- $Y^{*}$ : External Real GDP weighted by exports to all partner countries, from WEO (IMF).

- REER: CPI-based real effective exchange rate, from INS Database (IMF).

- ULCRE: Unit labor cost based real effective exchange rate, from European Commission.

\section{References}

Bayoumi, R., R. Harmsen and J. Turunen (2011), "Euro Area Export Performance and Competitiveness", IMF Working Paper No. 11/140.

WEF (2011a), The Travel and Tourism Competitiveness Report 2011, World Economic Forum, Geneva.

WEF (2011b), The Global Competitiveness Report 2011-2012, World Economic Forum, Geneva.

World Bank (2012), Doing Business 2012, The World Bank and International Finance Corporation, Washington DC. 